\title{
Three redescriptions in Tintinnopsis (Protista: Ciliophora: Tintinnina) from coastal waters of China, with cytology and phylogenetic analyses based on ribosomal RNA genes
}

Yang Bai ${ }^{1,2}$, Rui Wang ${ }^{1,2}$, Wen Song ${ }^{3}$, Lifang $\mathrm{Li}^{3}$, Luciana F. Santoferrara ${ }^{4}$ and Xiaozhong $\mathrm{Hu}^{1,2^{*}}$

\begin{abstract}
Background: The taxonomy of tintinnine ciliates is vastly unresolved because it has traditionally been based on the lorica (a secreted shell) and it has only recently incorporated cytological and molecular information. Tintinnopsis, the most speciose tintinnine genus, is also the most problematic: it is known to be non-monophyletic, but it cannot be revised until more of its species are studied with modern methods.

Results: Here, T. hemispiralis Yin, 1956, T. kiaochowensis Yin, 1956, and T. uruguayensis Balech, 1948, from coastal waters of China, were studied. Lorica and cell features were morphometrically investigated in living and protargolstained specimens, and sequences of three ribosomal RNA (rRNA) loci were phylogenetically analyzed. The three species show a complex ciliary pattern (with ventral, dorsal, and posterior kineties and right, left, and lateral ciliary fields), but differ in lorica morphology, details of the somatic ciliature and rRNA gene sequences. Tintinnopsis hemispiralis is further distinguished by a ciliary tuft (a ribbon of very long cilia originated from the middle portion of the ventral kinety and extending out of the lorica) and multiple macronuclear nodules. Both T. kiaochowensis and $T$. uruguayensis have two macronuclear nodules, but differ in the number of somatic kineties and the position of the posterior kinety. Two neotypes are fixed for T. hemispiralis and T. kiaochowensis to stabilize the species names objectively, mainly because of the previous unavailability of type materials. By phylogenetic analysis and comparison with closely-related species, we infer that the ciliary tuft and details such as the commencement of the rightmost kinety in the lateral ciliary field are synapomorphies that may help clarify the systematics of Tintinnopsis-like taxa.

Conclusion: The redescriptions of three poorly known Tintinnopsis species, namely T. hemispiralis, T. kiaochowensis, and T. uruguayensis firstly revealed their ciliary patterns and rRNA sequences. This study expands knowledge and database of tintinnines and helps in identifying potential synapomorphies for future taxonomic rearrangements.
\end{abstract}

Keywords: Ciliary pattern, Ciliary tuft, Lorica, Non-monophyly

\footnotetext{
* Correspondence: xiaozhonghu@ouc.edu.cn

'College of Fisheries, \& Key Laboratory of Mariculture, Ministry of Education, Ocean University of China, Qingdao 266003, China

${ }^{2}$ Institute of Evolution and Marine Biodiversity, Ocean University of China, Qingdao 266003, China

Full list of author information is available at the end of the article
}

(C) The Author(s). 2020 Open Access This article is licensed under a Creative Commons Attribution 4.0 International License, which permits use, sharing, adaptation, distribution and reproduction in any medium or format, as long as you give appropriate credit to the original author(s) and the source, provide a link to the Creative Commons licence, and indicate if changes were made. The images or other third party material in this article are included in the article's Creative Commons licence, unless indicated otherwise in a credit line to the material. If material is not included in the article's Creative Commons licence and your intended use is not permitted by statutory regulation or exceeds the permitted use, you will need to obtain permission directly from the copyright holder. To view a copy of this licence, visit http://creativecommons.org/licenses/by/4.0/ The Creative Commons Public Domain Dedication waiver (http://creativecommons.org/publicdomain/zero/1.0/) applies to the data made available in this article, unless otherwise stated in a credit line to the data. 


\section{Background}

Ciliated protists are among the most diverse and numerically important members of microzooplankton, and act as a trophic link in the microbial food web of aquatic ecosystems [1-5]. In particular, tintinnine ciliates are conspicuous due to the diversity of loricae produced by their cell propers. Tintinnines have been of great interest in the field of protistology because they (i) display distinct patterns of diversity and biogeography [6, 7]; (ii) serve as bioindicators of water quality and hydrological circulation [8-11]; (iii) are prey for fish larvae and other small metazoans [12, 13]; and (iv) can leave fossilized loricae that are useful in evolutionary studies [14, 15].

There are approximately 1000 extant tintinnine species classified almost entirely based on the shape and size of their loricae [16-21]. However, it is widely recognized that lorica features alone have shortcomings for determining taxonomic affiliations in this group of ciliates $[22,23]$. In some species, laboratory cultures have provided clear evidences that the lorica is polymorphic in response to environmental factors or in different stages of the life cycle [24]. More recently, DNA sequencing of several closely-related species has revealed examples of polymorphic and cryptic species [25, 26]. Thus, the current lorica-based taxonomy does not allow estimating tintinnine diversity accurately, and it does not provide a natural classification. Accordingly, several studies have incorporated more informative characters, namely, cytological and/ or molecular data, in tintinnine systematics (e.g., [27-36]). Still, cell characters and DNA sequences are only known for about 3 and $10 \%$ of the described tintinnine morphospecies, respectively (e.g., [22, 37]), and considerable efforts are needed to increase the availability of these types of information.

Arguably the most problematic taxon in tintinnine taxonomy is the genus Tintinnopsis Stein, 1867. This genus is known as artificial, given that it includes at least five distinct ciliary patterns $[22,33,38]$ and more than ten clades that are non-monophyletic in rDNA sequence analyses [39]. Out of the about 140 Tintinnopsis-like morphospecies [19-21], about 60 have been recorded in China seas (e.g. [21, 40-44]), but only a few count with ciliature and/or sequence data [34, 36, 45-48]. Overall, Tintinnopsis will need subdivision once its type, T. beroidea, and other species are studied with modern methods [22, 38, 39].

The present study investigates the morphology and molecular phylogeny of three Tintinnopsis species, namely, T. hemispiralis Yin, 1956, T. kiaochowensis Yin, 1956, and T. uruguayensis Balech, 1948, which were collected from coastal waters of China. This work includes observations of specimens in vivo and after protargol staining as well as phylogenetic analyses of ribosomal RNA gene markers based on recommendations for tintinnine taxonomy [23] and common practices for other ciliates [49]. The aims of the present study are to combine lorica, cell proper, and molecular data in three Tintinnopsis species and to compare them with related taxa in order to find potential diagnostic features relevant in this problematic tintinnine taxon.

\section{Zoobank registration}

The ZooBank registration number of the present work is: urn:lsid:zoobank.org:pub:38490F0B-183F-45AE-A05380FCA6799716.

\section{Results \\ Order Choreotrichida Small and Lynn, 1985 \\ Suborder Tintinnina Kofoid and Campbell, 1929 \\ Genus Tintinnopsis Stein, 1867 \\ Tintinnopsis hemispiralis Yin, 1956 (Figs. 1a-e, 2a- j; Table 1).}

\section{Terminology}

Tintinnopsis hemispiralis possesses a cluster of extremely long cilia that has only been reported for Tintinnopsis subacuta [50]. This character is here defined as follows.

Ciliary tuft. An extraordinary long tuft of cilia originated from densely arranged kinetids in the middle portion of the ventral kinety.

\section{Improved diagnosis (based on the type and neotype populations)}

Lorica $88-182 \mu \mathrm{m}$ long, comprising a cylindrical, spiraled collar and an obconical bowl. Opening 34-59 $\mu \mathrm{m}$ in diameter. Cell proper elongate, obconical when fully extended, size in vivo $80-125 \times 30-55 \mu \mathrm{m}$. Seven to 11 moniliform macronuclear nodules. On average 21 collar membranelles, of which four or five elongate into buccal cavity; one buccal membranelle. Ventral kinety composed of about 53 monokinetids, commences anteriorly to the second kinety of right ciliary field. Ciliary tuft about $150-250 \mu \mathrm{m}$ long. Right and left ciliary fields consist of about ten kineties each. Lateral ciliary field comprises on average 15 kineties. Dorsal kinety composed of about 47 dikinetids. Posterior kinety with about 17 dikinetids, positioned below left ciliary field.

\section{Deposition of neotype and other voucher materials}

A protargol slide including the neotype (Fig. 2f, g) was deposited in the Laboratory of Protozoology, Institute of Evolution and Marine Biodiversity, Ocean University of China (registration number: BY201805280101). One additional protargol slide was deposited in the same collection (registration number: BY201805280102). 


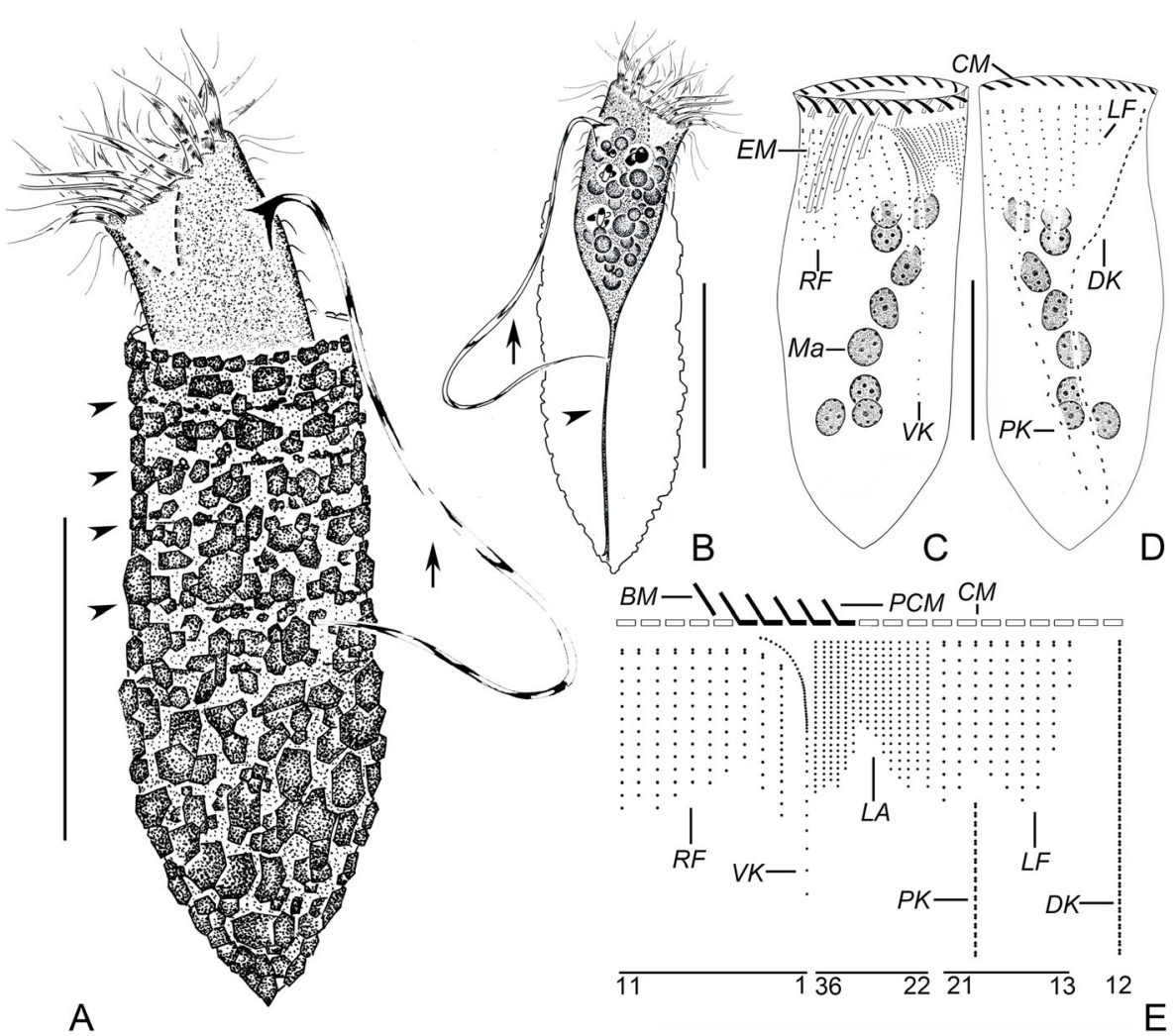

Fig. 1 Line drawings of Tintinnopsis hemispiralis in vivo $(\mathbf{a}, \mathbf{b})$ and after protargol staining (c-e) (from authors' own work). a Lateral view of a representative individual; arrow denotes the ciliary tuft; arrowheads mark the spiral striations on the collar portion of lorica. $\mathbf{b}$ Cell characters; arrow denotes the ciliary tuft; arrowhead shows peduncle. c, $\mathbf{d}$ Ventral (c) and dorsal (d) views of the same specimen, showing ciliary pattern and macronuclear nodules. e Kinetal map of a morphostatic specimen. BM, buccal membranelle; CM, collar membranelle; DK, dorsal kinety; EM, endoral membrane; LA, lateral ciliary field; LF, left ciliary field; Ma, macronuclear nodule; PCM, prolonged collar membranelle; PK, posterior kinety; $\mathrm{RF}$, right ciliary field; $\mathrm{VK}$, ventral kinety. Scale bars $=75 \mu \mathrm{m}(\mathbf{a}, \mathbf{b}), 30 \mu \mathrm{m}(\mathbf{c}, \mathbf{d})$

\section{Redescription based on the Ningde population}

Lorica 143-182 $\mu \mathrm{m}$ long, comprises a cylindrical, truncated collar and an obconical bowl (Figs. 1a, 2a-d). Opening $45-59 \mu \mathrm{m}$ across. Ratio of lorica length to opening diameter 2.9-3.2:1. Collar 64-97 $\mu \mathrm{m}$ long, with three to five inconspicuous spiraled striations (Figs. 1a, $2 \mathrm{~b})$. Bowl often slightly wider than opening (49-66 $\mu \mathrm{m}$ in diameter), about $68-88 \mu \mathrm{m}$ long, with a posterior angle of $45^{\circ}$ (Figs. 1a, 2b, c, d). Wall of lorica heterogeneously agglutinated with mineral particles: collar slightly less agglutinated than bowl because adhered particles sparser and thinner (Figs. 1a, 2b, c, d).

Cell proper $80-125 \mu \mathrm{m}$ long and $30-55 \mu \mathrm{m}$ wide in vivo in fully extended, $65-119 \mu \mathrm{m}$ long and $31-58 \mu \mathrm{m}$ wide protargol preparations (Figs. 1b, 2e). Posterior portion of cell proper narrows gradually forming a peduncle with a branched posterior end, which is about 60$110 \mu \mathrm{m}$ long and attaches to bottom of lorica (Figs. 1b, 2d, e). Seven to 11 moniliform macronuclear nodules, each about 5-10 long and 5-9 $\mu \mathrm{m}$ wide; anterior nodule $17-21 \mu \mathrm{m}$ posterior to the anterior cell end in protargolstained specimens (Figs. 1c, d, 2f, i, j). Micronuclei, striae, tentaculoids, accessory combs, a contractile vacuole, a cytopyge, and capsules not observed. Movement by irregular swimming with rotation about main cell axis.

Somatic ciliary pattern complex, that is, ventral kinety, dorsal kinety, posterior kinety, right ciliary field, left ciliary field, and lateral ciliary field present (Figs. 1c-e, 2fi). Ventral kinety begins anteriorly to the second kinety of right ciliary field, about $4-8 \mu \mathrm{m}$ below the anterior end of cell, goes around right ciliary field from left side before parallel to kineties of ciliary field posteriorly; 39$66 \mu \mathrm{m}$ long, with 41-61 monokinetids, composed of three portions: (1) anterior portion comprised of eight to 14 kinetids about $0.5-1 \mu \mathrm{m}$ apart; (2) middle portion consisting of 16-24 more densely arranged kinetids (with no measurable gap) with long cilia and forming the ciliary tuft, about $150-250 \mu \mathrm{m}$ long in vivo; (3) posterior portion containing sparsely arranged monokinetids (more than $1 \mu \mathrm{m}$ apart), extending posteriorly and terminating at about two thirds to three fourths of cell (Figs. 1a-c, e, 2c, f, g). Right ciliary field consists of 9-11 kineties, kineties about $2-5 \mu \mathrm{m}$ away from their 


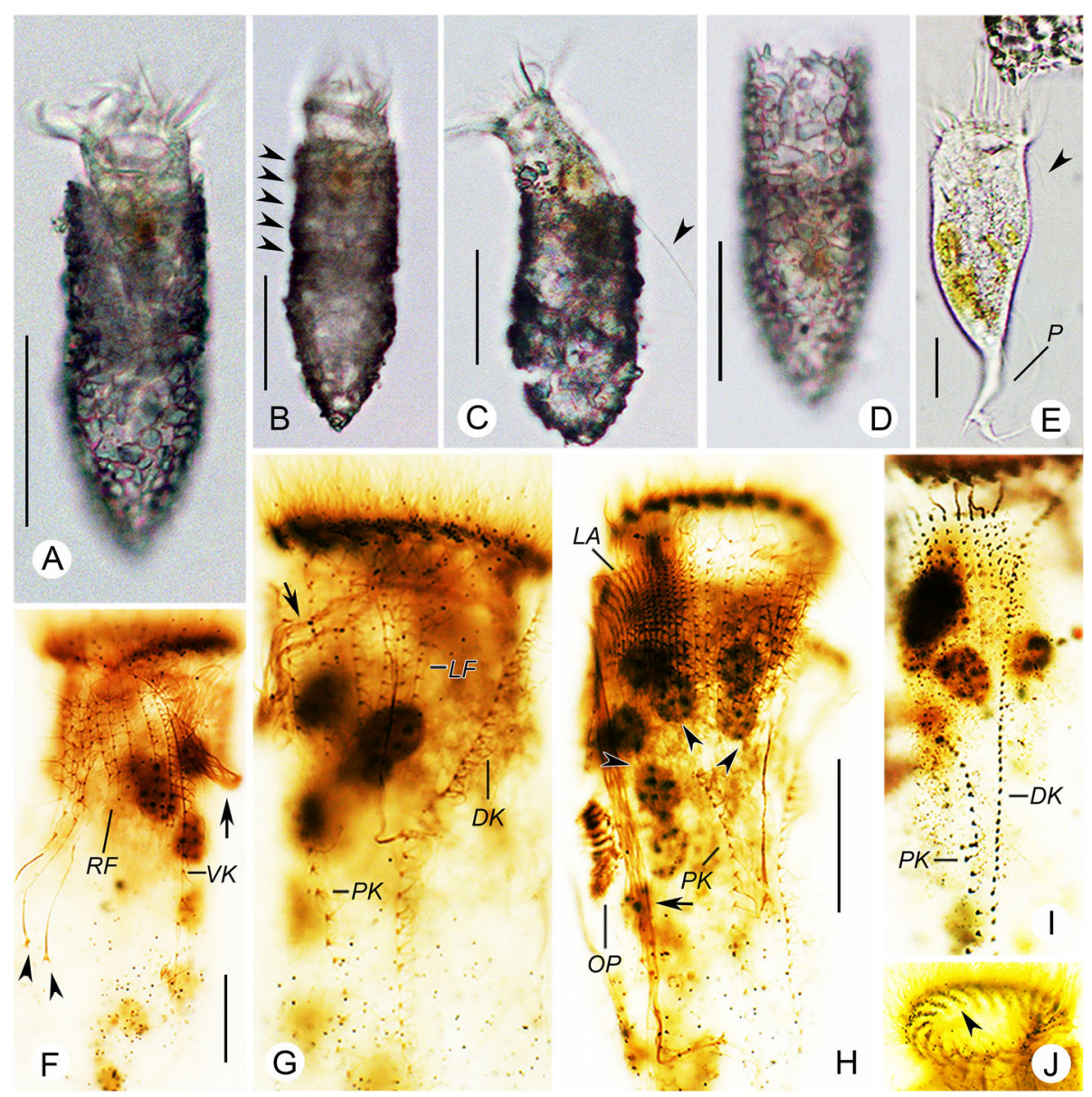

Fig. 2 Photomicrographs of Tintinnopsis hemispiralis in vivo $(\mathbf{a}-\mathbf{e})$ and after protargol staining $(\mathbf{f}-\mathbf{j})$. a Lateral view of a representative individual. $\mathbf{b}$ Arrowheads show the spiral striations on lorica. c Fully extended individual with broken lorica; arrowhead shows the ciliary tuft. $\mathbf{d}$ Lorica of another individual. e Cell proper that abandoned the lorica; arrowhead shows elongated anterior cilia. $\mathbf{f}$ Ventral kinety and right ciliary fields; arrow shows the ciliary tuft; arrowheads indicate the nodules of the thick argyrophilic fibers. $\mathbf{g}$ Dorsal side, showing the left ciliary field, dorsal kinety, and posterior kinety; arrow marks the ciliary tuft. $\mathbf{h}$ Lateral side of an early divider; arrowheads mark macronuclear nodules; arrow shows the ciliary tuft. i Posterior kinety and dorsal kinety. j Arrowhead marks collar membranelles. DK, dorsal kinety; LA, lateral ciliary field; LF, left ciliary field; $\mathrm{OP}$, oral primordium; PK, posterior kinety; RF, right ciliary field; P, peduncle; VK, ventral kinety. Scale bars $=75 \mu \mathrm{m}(\mathbf{a}, \mathbf{c}), 60 \mu \mathrm{m}(\mathbf{b}, \mathbf{d}), 25 \mu \mathrm{m}$ $(\mathbf{e}), 15 \mu \mathrm{m}(\mathbf{f}), 20 \mu \mathrm{m}(\mathbf{h})$

neighbors; each kinety has 5 to 18 monokinetids and one anterior dikinetid; kinetids of first kinety more densely arranged than those in the remaining kineties; all kineties commence at the same level (about $9 \mu \mathrm{m}$ below the anterior end of cell), except for the first kinety that starts about $2 \mu \mathrm{m}$ posteriorly to other kineties (Figs. 1c, e, 2f). Left ciliary field with 9-12 kineties, begins about $9 \mu \mathrm{m}$ below the anterior end of cell, kineties about $2-5 \mu \mathrm{m}$ away from their neighbors, composed of one anterior dikinetid and 2-13 monokinetids each; the leftmost two or three kineties always shorter, each only including three to five kinetids (Figs. 1c-e, $2 g-i)$. The anterior basal bodies of dikinetids in left and right ciliary fields bear elongated cilia, about $20 \mu \mathrm{m}$ long from life and $10 \mu \mathrm{m}$ long after protargol staining while the cilia on posterior basal bodies are similar to ones on monokinetid in length, about $3 \mu \mathrm{m}$ long after protargol staining (Figs. 1a, b, 2e, i). Lateral ciliary field commences about $9 \mu \mathrm{m}$ posteriorly to the anterior end of cell, comprises 11-20, relatively densely arranged monokinetidal kineties; kineties in middle region always shorter than those at both ends of field (i.e., including only half the number of kineties); cilia about $3 \mu \mathrm{m}$ long after silver staining (Figs. 1d, e, 2g, h). Dorsal kinety about $66-97 \mu \mathrm{m}$ in length and consisting of 35-56 dikinetids, commences about $5 \mu \mathrm{m}$ posteriorly to anterior cell end, about 5 and $10 \mu \mathrm{m}$ away from right and left ciliary field, respectively; only the posterior basal body bearing a cilium about $8-10 \mu \mathrm{m}$ long after protargol staining (Figs. 1d, e, 2g, i). Posterior kinety 37-58 $\mu \mathrm{m}$ long and consisting of 11-22 dikinetids, commences posteriorly to right portion of left ciliary field, with 29- 
Table 1 Morphometric data of Tintinnopsis hemispiralis, T. kiaochowensis, and T. uruguayensis (measurements in $\mu \mathrm{m}$ ). Lorica data are based on live specimens, and other data are based on protargol-stained specimens

\begin{tabular}{|c|c|c|c|c|c|c|c|c|}
\hline Characters & Species name & Min & Max & Mean & $M$ & SD & CV & $\mathrm{N}$ \\
\hline \multirow[t]{3}{*}{ Lorica, total length } & T. hemispiralis & 143 & 182 & 161.1 & 161 & 12.9 & 8.0 & 15 \\
\hline & T. kiaochowensis & 79 & 112 & 89.9 & 90 & 8.2 & 9.1 & 12 \\
\hline & T. uruguayensis & 50 & 73 & 62.3 & 62 & 7.7 & 12.4 & 15 \\
\hline \multirow[t]{3}{*}{ Lorica, bowl width } & T. hemispiralis & 49 & 66 & 55.9 & 57 & 5.1 & 9.2 & 15 \\
\hline & T. kiaochowensis & 57 & 81 & 66.7 & 65 & 7.4 & 11.0 & 12 \\
\hline & T. uruguayensis & 25 & 41 & 32.6 & 32 & 4.5 & 13.7 & 15 \\
\hline \multirow[t]{3}{*}{ Lorica, bowl length } & T. hemispiralis & 68 & 88 & 77.8 & 76 & 6.6 & 8.5 & 15 \\
\hline & T. kiaochowensis & 43 & 70 & 51.3 & 49 & 7.2 & 14.1 & 12 \\
\hline & T. uruguayensis & 32 & 52 & 39.0 & 39 & 5.7 & 14.6 & 13 \\
\hline \multirow[t]{3}{*}{ Lorica, collar length } & T. hemispiralis & 64 & 97 & 83.3 & 86 & 8.4 & 10.1 & 15 \\
\hline & T. kiaochowensis & 32 & 46 & 38.7 & 38 & 4.6 & 12.0 & 12 \\
\hline & T. uruguayensis & 11 & 22 & 16.6 & 16 & 3.2 & 19.4 & 15 \\
\hline \multirow[t]{3}{*}{ Lorica, opening diameter } & T. hemispiralis & 45 & 59 & 52.6 & 54 & 4.5 & 8.6 & 15 \\
\hline & T. kiaochowensis & 44 & 71 & 55.1 & 53 & 7.5 & 13.6 & 12 \\
\hline & T. uruguayensis & 24 & 42 & 33.1 & 33 & 5.4 & 16.4 & 15 \\
\hline \multirow[t]{3}{*}{ Lorica, length: opening diameter, ratio } & T. hemispiralis & 2.9 & 3.2 & 3.1 & 3.1 & 0.1 & 2.4 & 15 \\
\hline & T. kiaochowensis & 1.4 & 2.1 & 1.6 & 1.6 & 0.2 & 10.5 & 12 \\
\hline & T. uruguayensis & 1.6 & 2.3 & 1.9 & 1.9 & 0.2 & 8.2 & 15 \\
\hline \multirow[t]{2}{*}{ Lorica, narrowed portion diameter } & T. kiaochowensis & 38 & 63 & 48.8 & 47 & 7.7 & 15.9 & 12 \\
\hline & T. uruguayensis & 17 & 29 & 24.2 & 25 & 3.7 & 15.5 & 15 \\
\hline \multirow[t]{2}{*}{ Lorica, total length: narrowed portion diameter } & T. kiaochowensis & 1.4 & 2.2 & 1.9 & 2.0 & 0.3 & 16.2 & 12 \\
\hline & T. uruguayensis & 1.8 & 3.2 & 2.6 & 2.6 & 0.4 & 16.0 & 15 \\
\hline \multirow[t]{3}{*}{ Cell proper, length } & T. hemispiralis & 65 & 119 & 95.1 & 95 & 15.0 & 15.8 & 15 \\
\hline & T. kiaochowensis & 46 & 65 & 55.9 & 58 & 5.8 & 10.4 & 12 \\
\hline & T. uruguayensis & 25 & 56 & 31.5 & 30 & 7.4 & 23.5 & 15 \\
\hline \multirow[t]{3}{*}{ Cell proper, width } & T. hemispiralis & 31 & 58 & 44.5 & 47 & 8.3 & 18.6 & 15 \\
\hline & T. kiaochowensis & 38 & 64 & 45.5 & 42 & 6.5 & 14.4 & 12 \\
\hline & T. uruguayensis & 18 & 28 & 22.5 & 22 & 3.0 & 13.3 & 15 \\
\hline \multirow[t]{3}{*}{ Macronuclear nodules, number } & T. hemispiralis & 7 & 11 & 9.2 & 9 & 1.0 & 11.0 & 15 \\
\hline & T. kiaochowensis & 2 & 2 & 2.0 & 2 & 0.0 & 0.0 & 12 \\
\hline & T. uruguayensis & 2 & 2 & 2.0 & 2 & 0.0 & 0.0 & 15 \\
\hline \multirow[t]{3}{*}{ Macronuclear nodules, length } & T. hemispiralis & 5 & 10 & 8.7 & 9 & 1.3 & 14.9 & 15 \\
\hline & T. kiaochowensis & 15 & 22 & 18.4 & 18 & 2.4 & 12.8 & 12 \\
\hline & T. uruguayensis & 6 & 14 & 8.3 & 7 & 2.3 & 27.2 & 15 \\
\hline \multirow[t]{3}{*}{ Macronuclear nodules, width } & T. hemispiralis & 5 & 9 & 7.4 & 7 & 0.9 & 12.3 & 15 \\
\hline & T. kiaochowensis & 12 & 17 & 14.3 & 15 & 1.6 & 11.3 & 12 \\
\hline & T. uruguayensis & 4 & 10 & 5.8 & 5 & 1.8 & 31.4 & 15 \\
\hline \multirow[t]{3}{*}{ Anterior cell end to anterior macronucleus nodule, distance } & T. hemispiralis & 17 & 21 & 19.1 & 19 & 1.8 & 9.4 & 15 \\
\hline & T. kiaochowensis & 11 & 24 & 19.2 & 18 & 4.1 & 21.6 & 12 \\
\hline & T. uruguayensis & 4 & 9 & 6.3 & 6 & 1.4 & 22.1 & 15 \\
\hline \multirow[t]{3}{*}{ Ventral kinety, length } & T. hemispiralis & 39 & 66 & 56.6 & 55 & 5.2 & 9.3 & 15 \\
\hline & T. kiaochowensis & 22 & 37 & 32.3 & 34 & 4.7 & 14.5 & 12 \\
\hline & T. uruguayensis & 14 & 35 & 19.1 & 17 & 5.9 & 31.0 & 15 \\
\hline
\end{tabular}


Table 1 Morphometric data of Tintinnopsis hemispiralis, T. kiaochowensis, and T. uruguayensis (measurements in $\mu m$ ). Lorica data are based on live specimens, and other data are based on protargol-stained specimens (Continued)

\begin{tabular}{|c|c|c|c|c|c|c|c|c|}
\hline Characters & Species name & Min & Max & Mean & M & SD & CV & $\mathbf{N}$ \\
\hline \multirow[t]{3}{*}{ Ventral kinety, number of kinetids } & T. hemispiralis & 41 & 61 & 52.5 & 52 & 5.1 & 9.7 & 15 \\
\hline & T. kiaochowensis & 43 & 56 & 48.6 & 48 & 4.0 & 8.2 & 12 \\
\hline & T. uruguayensis & 17 & 28 & 20.3 & 21 & 2.3 & 11.3 & 15 \\
\hline \multirow[t]{3}{*}{ Ventral kinety, distance to anterior end of cell } & T. hemispiralis & 4 & 8 & 5.5 & 5 & 0.8 & 15.3 & 15 \\
\hline & T. kiaochowensis & 3 & 5 & 4.1 & 4 & 0.5 & 12.6 & 12 \\
\hline & T. uruguayensis & 2 & 3 & 2.3 & 2 & 0.5 & 20.9 & 15 \\
\hline \multirow[t]{3}{*}{ Dorsal kinety, length } & T. hemispiralis & 66 & 97 & 88.8 & 90 & 6.1 & 6.9 & 15 \\
\hline & T. kiaochowensis & 29 & 53 & 43.8 & 43 & 6.5 & 14.8 & 12 \\
\hline & T. uruguayensis & 21 & 41 & 26.5 & 24 & 5.5 & 20.8 & 15 \\
\hline \multirow[t]{3}{*}{ Dorsal kinety, number of kinetids } & T. hemispiralis & 35 & 56 & 46.5 & 43 & 4.7 & 10.2 & 15 \\
\hline & T. kiaochowensis & 25 & 37 & 31.2 & 31 & 4.4 & 14.3 & 12 \\
\hline & T. uruguayensis & 17 & 29 & 21.1 & 20 & 3.5 & 16.7 & 15 \\
\hline \multirow[t]{3}{*}{ Dorsal kinety, distance to right ciliary field } & T. hemispiralis & 4 & 6 & 4.5 & 4 & 0.6 & 14.1 & 15 \\
\hline & T. kiaochowensis & 4 & 6 & 4.7 & 5 & 0.7 & 14.0 & 12 \\
\hline & T. uruguayensis & 2 & 3 & 2.2 & 2 & 0.4 & 18.2 & 15 \\
\hline \multirow[t]{3}{*}{ Dorsal kinety, distance to left ciliary field } & T. hemispiralis & 8 & 14 & 10.4 & 11 & 1.1 & 10.8 & 15 \\
\hline & T. kiaochowensis & 11 & 21 & 13.2 & 13 & 2.6 & 19.7 & 12 \\
\hline & T. uruguayensis & 2 & 5 & 3.2 & 3 & 0.7 & 21.8 & 15 \\
\hline \multirow[t]{3}{*}{ Dorsal kinety, distance to anterior end of cell } & T. hemispiralis & 4 & 7 & 4.9 & 5 & 1.0 & 20.9 & 15 \\
\hline & T. kiaochowensis & 3 & 6 & 4.4 & 5 & 0.9 & 20.4 & 12 \\
\hline & T. uruguayensis & 2 & 3 & 2.3 & 2 & 0.5 & 20.9 & 15 \\
\hline \multirow[t]{3}{*}{ Posterior kinety, length } & T. hemispiralis & 37 & 58 & 45.9 & 45 & 5.3 & 11.5 & 15 \\
\hline & T. kiaochowensis & 21 & 29 & 25.5 & 27 & 3.1 & 12.2 & 11 \\
\hline & T. uruguayensis & 11 & 22 & 13.7 & 12 & 2.9 & 21.0 & 15 \\
\hline \multirow[t]{3}{*}{ Posterior kinety, number of kinetids } & T. hemispiralis & 11 & 22 & 17.0 & 17 & 2.7 & 15.7 & 15 \\
\hline & T. kiaochowensis & 11 & 18 & 15.4 & 15 & 2.0 & 12.8 & 11 \\
\hline & T. uruguayensis & 7 & 9 & 8.0 & 8 & 0.5 & 6.7 & 15 \\
\hline \multirow[t]{3}{*}{ Posterior kinety, distance to anterior end of cell } & T. hemispiralis & 29 & 41 & 34.9 & 34 & 3.4 & 9.7 & 15 \\
\hline & T. kiaochowensis & 28 & 49 & 36.0 & 35 & 5.3 & 14.6 & 12 \\
\hline & T. uruguayensis & 12 & 21 & 15.5 & 15 & 2.5 & 16.1 & 15 \\
\hline \multirow[t]{3}{*}{ Right ciliary field, number of kineties } & T. hemispiralis & 9 & 11 & 9.7 & 9 & 0.8 & 8.4 & 15 \\
\hline & T. kiaochowensis & 10 & 13 & 11.4 & 12 & 0.9 & 7.9 & 12 \\
\hline & T. uruguayensis & 7 & 8 & 7.3 & 7 & 0.5 & 6.3 & 15 \\
\hline \multirow[t]{3}{*}{ Longest kinety in right field, length } & T. hemispiralis & 16 & 26 & 19.7 & 19 & 2.5 & 12.7 & 15 \\
\hline & T. kiaochowensis & 19 & 28 & 24.3 & 25 & 2.5 & 10.4 & 12 \\
\hline & T. uruguayensis & 7 & 14 & 10.3 & 10 & 2.2 & 20.9 & 15 \\
\hline \multirow[t]{3}{*}{ Longest kinety in right field, number of kinetids } & T. hemispiralis & 15 & 19 & 16.6 & 16 & 1.0 & 5.9 & 15 \\
\hline & T. kiaochowensis & 11 & 15 & 12.4 & 12 & 1.1 & 8.7 & 12 \\
\hline & T. uruguayensis & 7 & 9 & 7.4 & 7 & 0.6 & 8.5 & 15 \\
\hline \multirow[t]{3}{*}{ Shortest kinety in right field, length } & T. hemispiralis & 6 & 16 & 10.7 & 11 & 2.0 & 18.5 & 15 \\
\hline & T. kiaochowensis & 9 & 17 & 13.5 & 14 & 1.8 & 13.6 & 12 \\
\hline & T. uruguayensis & 3 & 6 & 4.5 & 4 & 0.9 & 20.5 & 15 \\
\hline Shortest in right field, number of kinetids & T. hemispiralis & 6 & 11 & 8.6 & 8 & 2.2 & 25.2 & 15 \\
\hline
\end{tabular}


Table 1 Morphometric data of Tintinnopsis hemispiralis, T. kiaochowensis, and T. uruguayensis (measurements in $\mu m$ ). Lorica data are based on live specimens, and other data are based on protargol-stained specimens (Continued)

\begin{tabular}{|c|c|c|c|c|c|c|c|c|}
\hline Characters & Species name & Min & Max & Mean & M & SD & CV & $\mathrm{N}$ \\
\hline & T. kiaochowensis & 6 & 7 & 6.5 & 7 & 0.5 & 8.0 & 12 \\
\hline & T. uruguayensis & 2 & 3 & 2.8 & 3 & 0.4 & 14.8 & 15 \\
\hline \multirow[t]{3}{*}{ Left ciliary field, number of kineties } & T. hemispiralis & 9 & 12 & 9.8 & 9 & 1.0 & 10.3 & 15 \\
\hline & T. kiaochowensis & 9 & 11 & 9.9 & 10 & 0.7 & 6.7 & 12 \\
\hline & T. uruguayensis & 6 & 8 & 6.6 & 6 & 0.8 & 12.5 & 15 \\
\hline \multirow[t]{3}{*}{ Longest kinety in left field, length } & T. hemispiralis & 17 & 28 & 23.3 & 24 & 3.3 & 14.0 & 15 \\
\hline & T. kiaochowensis & 11 & 16 & 12.5 & 12 & 1.4 & 11.6 & 12 \\
\hline & T. uruguayensis & 7 & 11 & 9.1 & 9 & 1.1 & 12.3 & 15 \\
\hline \multirow[t]{3}{*}{ Longest kinety in left field, number of kinetids } & T. hemispiralis & 11 & 14 & 12.7 & 13 & 0.8 & 6.3 & 15 \\
\hline & T. kiaochowensis & 8 & 9 & 8.8 & 9 & 0.5 & 5.2 & 12 \\
\hline & T. uruguayensis & 6 & 8 & 7.3 & 7 & 0.6 & 8.2 & 15 \\
\hline \multirow[t]{3}{*}{ Shortest kinety in left field, length } & T. hemispiralis & 4 & 8 & 5.8 & 6 & 1.3 & 22.8 & 15 \\
\hline & T. kiaochowensis & 4 & 7 & 5.8 & 6 & 1.0 & 17.7 & 12 \\
\hline & T. uruguayensis & 3 & 6 & 4.6 & 4 & 0.9 & 19.8 & 15 \\
\hline \multirow[t]{3}{*}{ Shortest kinety in left field, number of kinetids } & T. hemispiralis & 3 & 5 & 3.7 & 4 & 0.6 & 15.9 & 15 \\
\hline & T. kiaochowensis & 3 & 4 & 3.6 & 4 & 0.5 & 14.4 & 12 \\
\hline & T. uruguayensis & 2 & 2 & 2.0 & 2 & 0.0 & 0.0 & 15 \\
\hline \multirow[t]{3}{*}{ Lateral ciliary field, number of kineties } & T. hemispiralis & 11 & 20 & 15.4 & 15 & 2.3 & 7.7 & 15 \\
\hline & T. kiaochowensis & 13 & 19 & 15.9 & 15 & 1.8 & 11.5 & 12 \\
\hline & T. uruguayensis & 9 & 16 & 11.9 & 11 & 2.3 & 19.1 & 15 \\
\hline \multirow[t]{3}{*}{ Lateral ciliary field, length of the longest kinety } & T. hemispiralis & 9 & 17 & 12.4 & 12 & 1.5 & 12.5 & 15 \\
\hline & T. kiaochowensis & 22 & 33 & 28.9 & 31 & 4.0 & 13.7 & 12 \\
\hline & T. uruguayensis & 9 & 14 & 11.8 & 12 & 1.6 & 13.7 & 15 \\
\hline \multirow[t]{3}{*}{ Lateral ciliary field, length of the shortest kinety } & T. hemispiralis & 4 & 8 & 6.3 & 6 & 1.0 & 16.5 & 15 \\
\hline & T. kiaochowensis & 9 & 19 & 13.4 & 14 & 2.7 & 20.5 & 12 \\
\hline & T. uruguayensis & 7 & 11 & 9.5 & 10 & 1.4 & 14.9 & 15 \\
\hline \multirow[t]{3}{*}{ Kineties in ciliary field, distance to anterior end of cell } & T. hemispiralis & 7 & 12 & 9.3 & 9 & 1.5 & 16.0 & 15 \\
\hline & T. kiaochowensis & 6 & 13 & 9.4 & 9 & 1.9 & 20.0 & 12 \\
\hline & T. uruguayensis & 2 & 3 & 2.3 & 2 & 0.5 & 20.9 & 15 \\
\hline \multirow[t]{3}{*}{ Adoral zone of membranelles, diameter } & T. hemispiralis & 27 & 57 & 40.7 & 40 & 8.5 & 20.8 & 15 \\
\hline & T. kiaochowensis & 33 & 52 & 42.9 & 42 & 5.2 & 12.0 & 12 \\
\hline & T. uruguayensis & 12 & 21 & 17.0 & 17 & 1.9 & 11.1 & 15 \\
\hline \multirow[t]{3}{*}{ Collar membranelles, number } & T. hemispiralis & 20 & 22 & 21.3 & 21 & 0.7 & 3.4 & 15 \\
\hline & T. kiaochowensis & 16 & 18 & 16.3 & 16 & 0.5 & 2.8 & 12 \\
\hline & T. uruguayensis & 18 & 19 & 18.2 & 18 & 0.4 & 2.3 & 15 \\
\hline \multirow[t]{3}{*}{ Buccal membranelle, number } & T. hemispiralis & 1 & 1 & 1.0 & 1 & 0.0 & 0.0 & 15 \\
\hline & T. kiaochowensis & 1 & 1 & 1.0 & 1 & 0.0 & 0.0 & 12 \\
\hline & T. uruguayensis & 1 & 1 & 1.0 & 1 & 0.0 & 0.0 & 15 \\
\hline \multirow[t]{3}{*}{ Prolonged membranelles, number } & T. hemispiralis & 4 & 5 & 4.7 & 5 & 0.5 & 10.5 & 15 \\
\hline & T. kiaochowensis & 3 & 3 & 3.0 & 3 & 0.0 & 0.0 & 12 \\
\hline & T. uruguayensis & 3 & 4 & 3.3 & 3 & 0.5 & 14.0 & 15 \\
\hline
\end{tabular}

Abbreviations: CV Coefficient of variation in \%, M Median, Max Maximum, Mean Arithmetic mean, Min Minimum, $N$ Number of specimens examined, SD Standard deviation 
$41 \mu \mathrm{m}$ away from the anterior cell end and curves rightwards; only the posterior basal body bearing a cilium about 8-10 $\mu \mathrm{m}$ long after protargol staining (Figs. 1d, e, 2g-i).

Adoral zone of membranelles composed of 20-22 collar membranelles with, four or five of which extend into buccal cavity with longest bases about $30 \mu \mathrm{m}$; cilia in collar membranelles about 25-35 $\mu \mathrm{m}$ in length; polykinetid structures could not be recognized (Figs. 1a-e, 2a-e, j). Single buccal membranelle within buccal cavity, with polykinetid about $40 \mu \mathrm{m}$ long (Fig. 1c, e). Argyrophilic fibers originate in the proximal portions of the elongated collar membranelles and the buccal membranelle, and extend posteriorly; three thick fibers commencing from the middle of cell below right ciliary field and extending towards anterior part of cell; ends not observed due to insufficient staining (Fig. 2f). Endoral membrane consisting of a single row of basal bodies, extends in a semicircle across the peristomial field and right wall of buccal cavity (Fig. 1c). An early divider was observed with the oral primordium posterior to the ventral kinety and lateral ciliary field (Fig. 2h).

Tintinnopsis kiaochowensis Yin, 1956 (Figs. 3a-e, 4ak; Table 1).

\section{Improved diagnosis (based on the type and neotype populations)}

Lorica $79-112 \mu \mathrm{m}$ in length, composed of an irregular collar and an ellipsoidal bowl with a rounded posterior end, both separated by a constriction. Opening 30$71 \mu \mathrm{m}$ in diameter. Cell proper obconical when fully extended, size in vivo about $60-95 \times 35-50 \mu \mathrm{m}$. Two ellipsoidal macronuclear nodules. On average 16 collar membranelles, three of which extend into buccal cavity; one buccal membranelle. Ventral kinety with an average of 49 densely arranged monokinetids. Right, left, and lateral ciliary fields include, on average, 11, 10, and 16 kineties, respectively. Dorsal kinety composed of about 31 dikinetids. Posterior kinety composed of about 15 dikinetids, positioned below lateral ciliary field.

\section{Deposition of neotype and other voucher materials}

A protargol slide including the neotype (Fig. 4h, i) was deposited in the Laboratory of Protozoology, Institute of Evolution and Marine Biodiversity, Ocean University of China (registration number: BY201805280201). One additional protargol slide was deposited in the same collection (registration number: BY201805280202).

\section{Redescription based on the Ningde population}

Lorica $79-112 \mu \mathrm{m}$ in length, composed of an irregular collar and an ellipsoidal bowl (Figs. 3a, 4a-c). Opening $44-71 \mu \mathrm{m}$ in diameter; rim irregular. Ratio of lorica

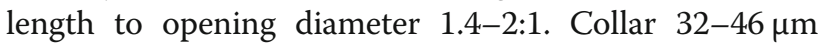
high, not flaring at the opening margin, occasionally slightly layered because of agglutinated particles

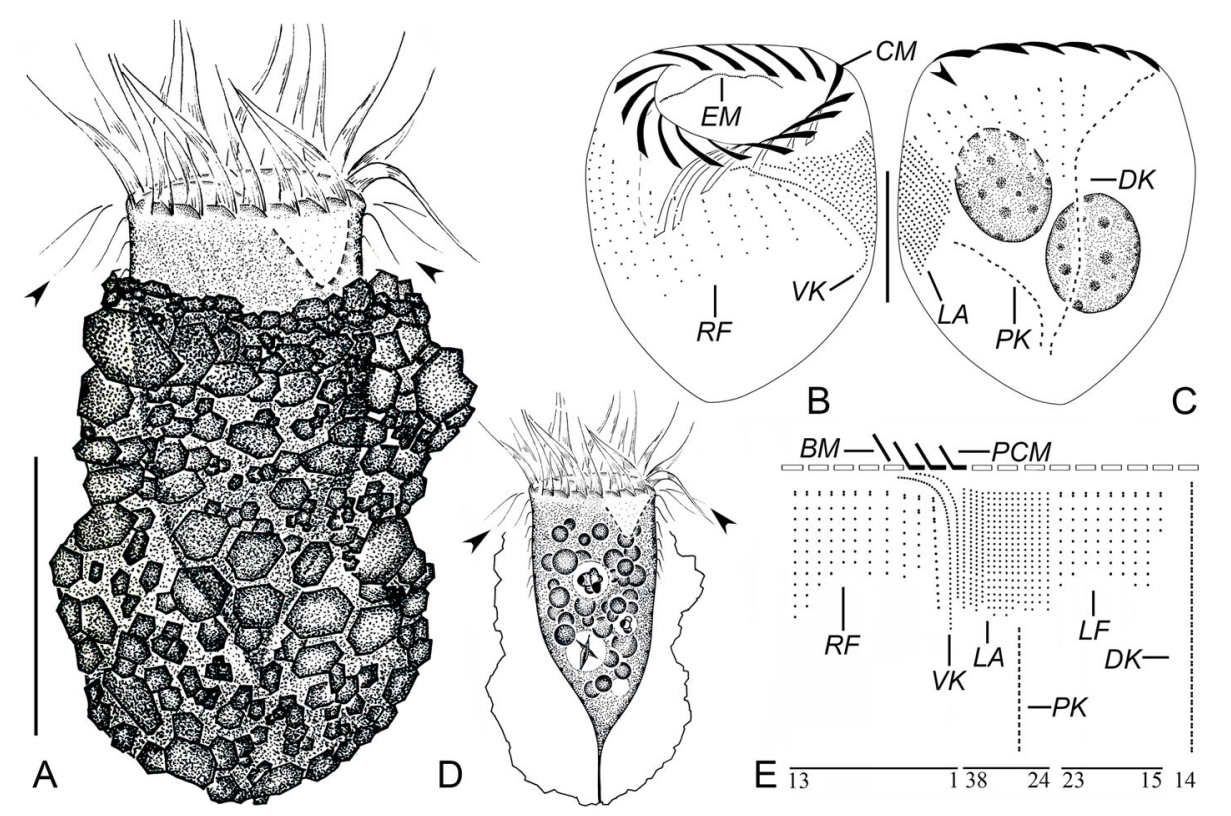

Fig. 3 Line drawings of Tintinnopsis kiaochowensis in vivo (a, d) and after protargol staining (b, $\mathbf{c}, \mathbf{e})$ (from authors' own work). $\mathbf{a}$ Lateral view of a representative individual; arrowheads mark elongated anterior cilia of right and left ciliary field. $\mathbf{b}, \mathbf{c}$, Ventral (b) and dorsal (c) views of the same specimen, showing ciliary pattern and macronuclear nodules; arrowhead denotes the left ciliary field. $\mathbf{d}$ Cell features; arrowheads mark elongated anterior cilium of the right and left ciliary fields; arrow shows peduncle. e Kinetal map of a morphostatic specimen. BM, buccal membranelle; CM, collar membranelle; DK, dorsal kinety; LA, lateral ciliary field; LF, left ciliary field; PCM, prolonged collar membranelle; PK, posterior kinety; RF, right ciliary field; VK, ventral kinety. Scale bars $=50 \mu \mathrm{m}(\mathbf{a}), 20 \mu \mathrm{m}(\mathbf{b}, \mathbf{c}), 40 \mu \mathrm{m}(\mathbf{d})$ 


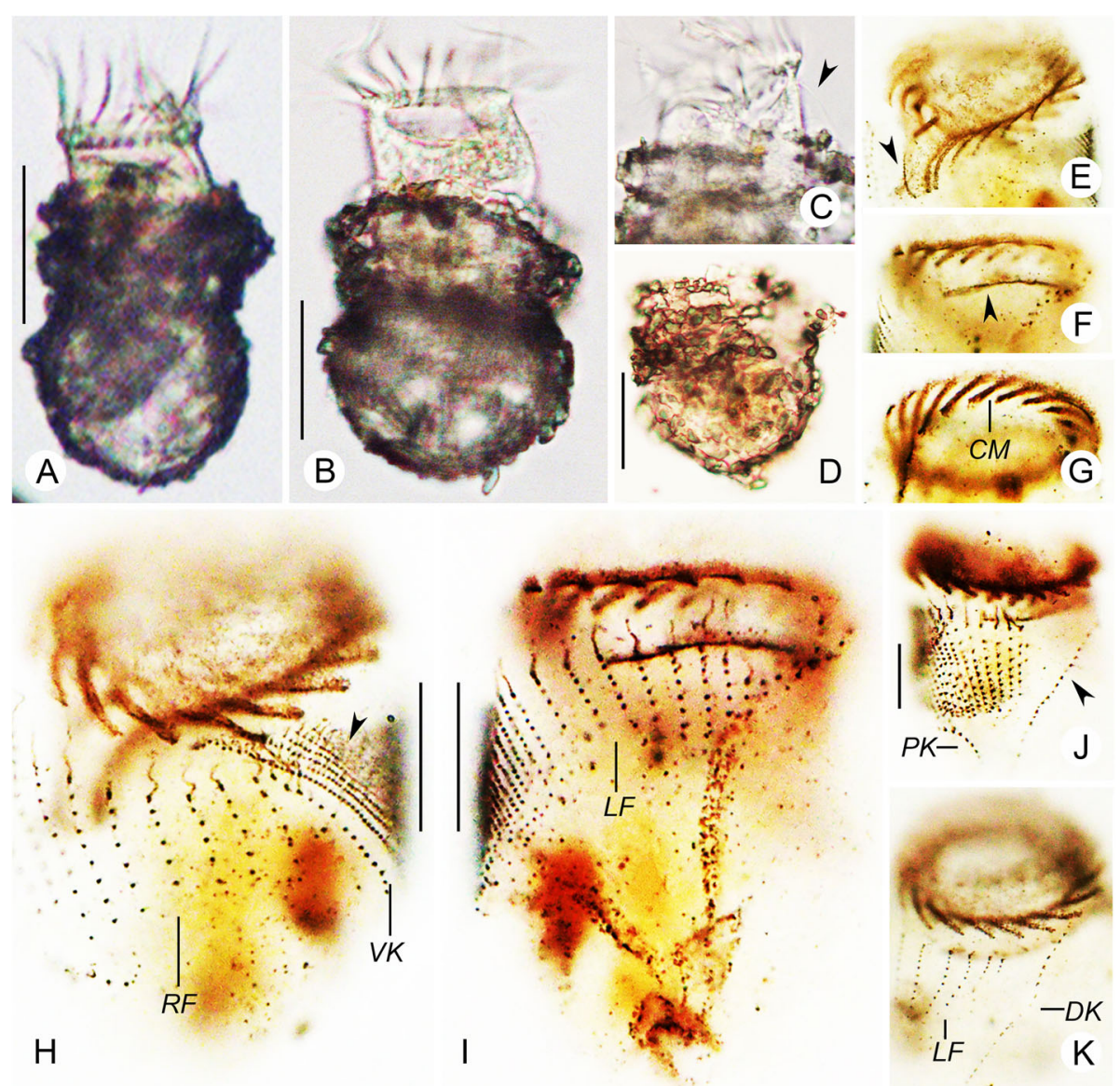

Fig. 4 Photomicrographs of Tintinnopsis kiaochowensis in vivo (a-d) and after protargol staining (e-k). a Lateral view of a representative individual. b Different individual showing lorica variation. c Elongated anterior cilia of the right and left ciliary fields (arrowhead). $\mathbf{d}$ Pressed lorica showing aligned particles. e, $\mathbf{f}$ Arrowheads mark endoral membrane. $\mathbf{g}$ Collar membranelles. $\mathbf{h}$ Ventral side; arrowhead shows the lateral ciliary field. i Dorsal side of the same specimen as in (h). $\mathbf{j}$ Dorsal (arrowhead) and posterior kinety. $\mathbf{k}$ Subapical view, showing the left ciliary field and dorsal kinety. CM, collar membranelle; DK, dorsal kinety; LF, left ciliary field; PK, posterior kinety; RF, right ciliary field; VK, ventral kinety. Scale bars $=45 \mu \mathrm{m}(\mathbf{a}, \mathbf{b}, \mathbf{d}), 15 \mu \mathrm{m}(\mathbf{h}, \mathbf{i}), 20 \mu \mathrm{m}(\mathbf{j})$

arranged in horizontal rows (Figs. 3a, 4a-c). Region between collar and bowl constricted, about $38-63 \mu \mathrm{m}$ in diameter (Figs. 3a, 4a, b). Bowl about $43-70 \mu \mathrm{m}$ long and $57-83 \mu \mathrm{m}$ across. Posterior end usually rounded to bluntly tapered (Figs. 3a, 4a, b).

Cell proper about $60-95 \mu \mathrm{m}$ long and $35-50 \mu \mathrm{m}$ wide from life when it is fully extended, $46-65 \mu \mathrm{m}$ long and $38-64 \mu \mathrm{m}$ wide in protargol preparation. Posterior cell portion narrows successively forming a peduncle about $25 \mu \mathrm{m}$ long and attached to the bottom of lorica (Figs. 3a, d, 4b). Two ellipsoidal macronuclear nodules, each about $15-22 \times 12-17 \mu \mathrm{m}$ in protargol-stained specimens; anterior nodule $11-24 \mu \mathrm{m}$ from the anterior cell end (Fig. 3c). Micronuclei, striae, tentaculoids, accessory combs, contractile vacuole, cytopyge, and capsules not observed. Locomotion by rotation about main cell axis.

Somatic ciliary pattern complex, that is, ventral kinety, dorsal kinety, posterior kinety, right ciliary field, left ciliary field, and lateral ciliary field present (Figs. 3b, c, e, 4h-k). Ventral kinety 22-37 $\mu \mathrm{m}$ long, commences anteriorly to third or fourth kinety of right ciliary field and about $4 \mu \mathrm{m}$ below the anterior cell end, anterior third curves leftwards before extending parallel to kineties of lateral ciliary field posteriorly; 43-56 densely arranged monokinetids (Figs. 3b, e, 4h). Right ciliary field consists of $10-13$ kineties about $2-5 \mu \mathrm{m}$ away from each other, the space between the leftmost five to six kineties wider than others; all kineties commence $6-13 \mu \mathrm{m}$ below the anterior end of cell; composed of 5-14 widely spaced monokinetids and one anterior dikinetid, except for: (i) the first kinety almost parallel to ventral kinety, with two or three anterior dikinetids and eight to 12 monokinetids, more densely arranged than other kineties in right ciliary field; and (ii) the second kinety parallel to rest of kineties, with an angle of about $20^{\circ}$ with the first kinety, including four or five monokinetids and two anterior dikinetids (Figs. 3b, e, 4h). Left ciliary field consists of 911 kineties $2-5 \mu \mathrm{m}$ away from each other, each kinety 
commences $6-13 \mu \mathrm{m}$ posteriorly to the anterior cell end and comprises of two to eight monokinetids and one anterior dikinetid; the number of kinetids of leftmost kinety always minimum (i.e., three or four). The anterior basal bodies of dikinetids in left and right ciliary field bear elongated cilia, about $15 \mu \mathrm{m}$ long from life and $5 \mu \mathrm{m}$ long after protargol staining while the cilia on posterior basal bodies with similar length to monokinetid-based ones, about $1 \mu \mathrm{m}$ long after protargol staining (Figs. 3a, d, 4c, h-j). Lateral ciliary field comprises 13-19 monokinetidal kineties of similar length, each apart 6-13 $\mu \mathrm{m}$ from the anterior cell end, except for the rightmost kinety that commences anteriorly to the second or third kinety of right ciliary field, about $4 \mu \mathrm{m}$ below the anterior cell end, with the anterior portion curving rightwards before extending towards posterior part; cilia about $2 \mu \mathrm{m}$ long after protargol staining (Figs. 3b, c, e, 4h, i). Dorsal kinety 29-53 $\mu \mathrm{m}$ long, comprises $25-37$ dikinetids, apart about $4 \mu \mathrm{m}$ from the anterior cell end, about $5 \mu \mathrm{m}$ from right ciliary field and $13 \mu \mathrm{m}$ from left ciliary field (Figs. 3c, e, 4j, k). Posterior kinety 21-29 $\mu \mathrm{m}$ long, consists of 11-18 dikinetids, commences posteriorly to lateral ciliary field, with $28-49 \mu \mathrm{m}$ away from the anterior cell end (Figs. 3c, e, 4j). Cilia of dorsal and posterior kinety are insufficiently stained.
Adoral zone of membranelles comprises 16-18 collar membranelles with cilia about $25-35 \mu \mathrm{m}$ long, three of which extend into buccal cavity; the longest bases about $30 \mu \mathrm{m}$; kinetal structures of membranelles could not be recognized (Figs. 3a-e, 4e-g, h). Single buccal membranelle in buccal cavity, with polykinetid about $20 \mu \mathrm{m}$ long (Figs. 3b, e, 4e). Endoral membrane comprised of a single row of basal bodies, extends in a semicircle across the peristomial field and right wall of buccal cavity (Figs. 3b, c, 4e, f). Argyrophilic fibers associated with oral apparatus insufficiently impregnated to be observed.

Tintinnopsis uruguayensis Balech, 1948 (Figs. 5ad, 6a-j; Table 1).

\section{Improved diagnosis (based on the type and present populations)}

Lorica $50-73 \mu \mathrm{m}$ long, bullet-like with a flared collar and a posterior process about $8-10 \mu \mathrm{m}$ long. Opening $22-42 \mu \mathrm{m}$ in diameter, with an irregular rim. Cell proper obconical when fully extended, size in vivo about 25$50 \mu \mathrm{m} \times 20-30 \mu \mathrm{m}$. Two macronuclear nodules. On average 18 collar membranelles, of which three or four extend into buccal cavity; one buccal membranelle. Ventral kinety composed of about 20 monokinetids. Right

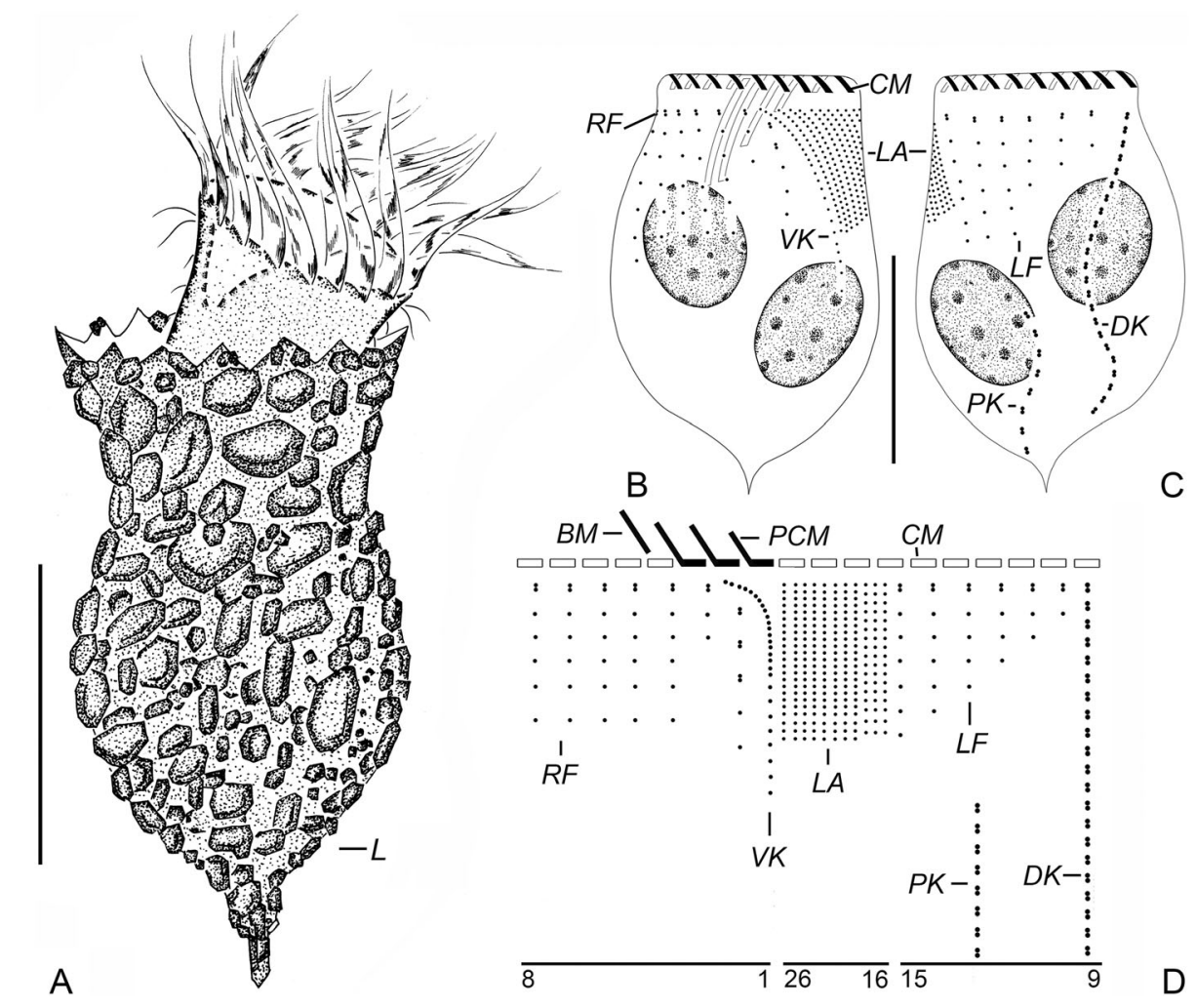

Fig. 5 Line drawings of Tintinnopsis uruguayensis in vivo (a) and after protargol staining (b-d) (from authors' own work). a Lateral view of a representative individual. b, c Ventral (b) and dorsal (c) views of the same specimen, showing ciliary pattern and macronuclear nodules. $\mathbf{d}$ Kinetal map of a morphostatic specimen. BM, buccal membranelle; CM, collar membranelle; DK, dorsal kinety; L, lorica; LA, lateral ciliary field; LF, left ciliary field; PCM, prolonged collar membranelle; PK, posterior kinety; RF, right ciliary field; VK, ventral kinety. Scale bars $=30 \mu \mathrm{m}(\mathbf{a}), 15 \mu \mathrm{m}(\mathbf{b}, \mathbf{c})$ 

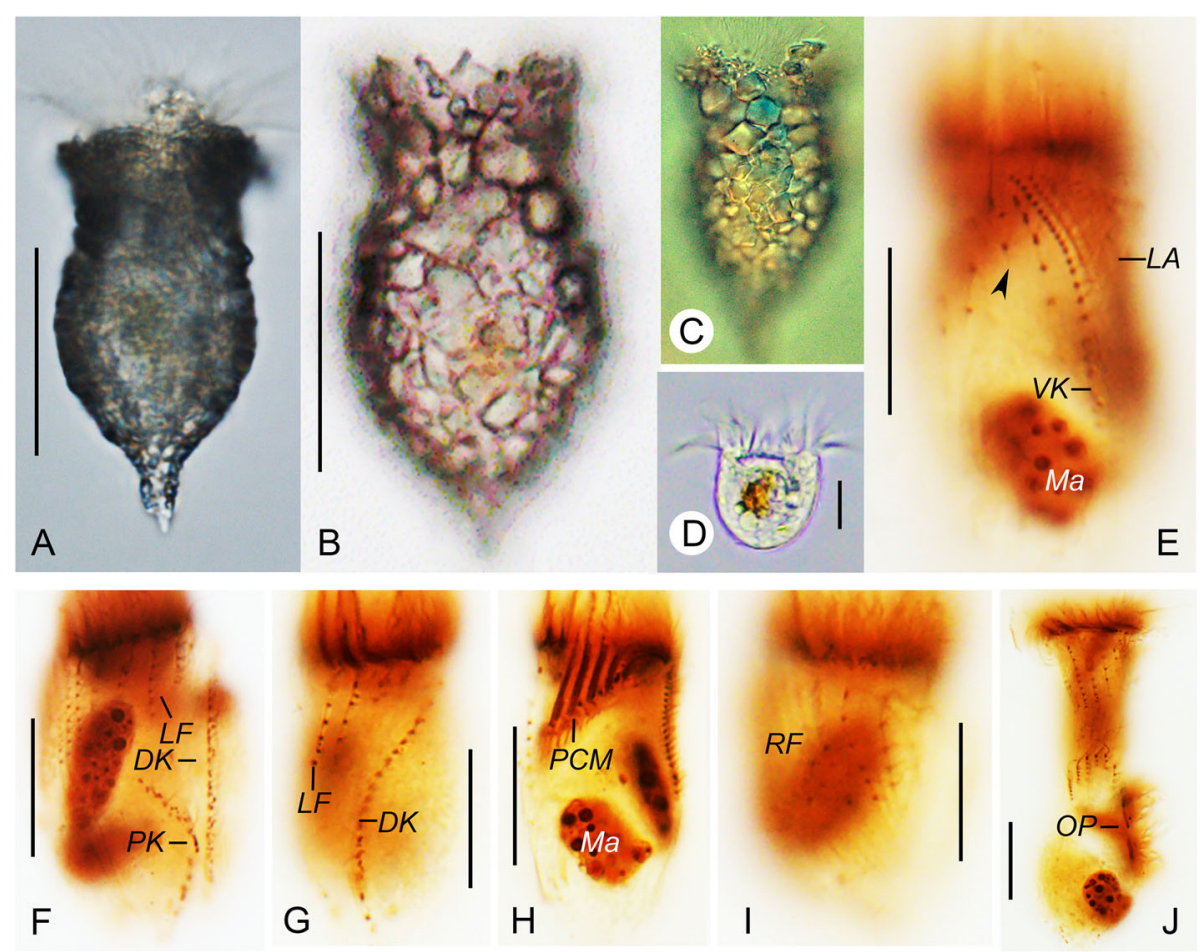

Fig. 6 Photomicrographs of Tintinnopsis uruguayensis in vivo (a-d) and after protargol staining (e-j). a Lateral view of a representative individual. b Lorica showing a flared collar with jagged rim. c Lorica with atypical collar rim. d Cell proper escaped from lorica. e Ventral side; arrowhead indicates the second short kinety in the right ciliary field. $\mathbf{f}$ Left ciliary field and dorsal kinety. $\mathbf{g}$ Dorsal kinety. $\mathbf{h}$ Prolonged collar membranelles and macronuclear nodules. i Right ciliary field. $\mathbf{j}$ Lateral view of a middle divider. DK, dorsal kinety; LF, left ciliary field; Ma, macronuclear nodule; $\mathrm{OP}$, oral primordium; PK, posterior kinety; RF, right ciliary field; VK, ventral kinety. Scale bars $=30 \mu \mathrm{m}(\mathbf{a}, \mathbf{b}), 15 \mu \mathrm{m}(\mathbf{d}-\mathbf{k})$

and left ciliary fields consist of about seven kineties each. Lateral ciliary field comprises on average 12 kineties. Dorsal kinety with about 21 dikinetids. Posterior kinety with about eight dikinetids, posterior to lateral ciliary field.

\section{Deposition of voucher materials}

Two protargol slides with voucher specimens were deposited in the Laboratory of Protozoology, Institute of Evolution and Marine Biodiversity, Ocean University of China (registration numbers: BY201811120101 and BY201811120102).

\section{Redescription based on the Qingdao population}

Lorica 50-73 $\mu \mathrm{m}$ long, composed of a flared collar about $15 \mu \mathrm{m}$ long with a jagged rim, and an ovoidal bowl about 32-52 $\mu \mathrm{m}$ long and 25-41 $\mu \mathrm{m}$ wide (Figs. 5a, 6a-c). Opening diameter $24-42 \mu \mathrm{m}$. Region between collar and bowl narrowed, about $17-29 \mu \mathrm{m}$ in diameter (Figs. 5a, $6 \mathrm{a}-\mathrm{c})$. Posterior end projected, about $10 \mu \mathrm{m}$ long (Figs. 5a, 6a). Wall of lorica heterogeneously agglutinated with mineral particles (Figs. 5a, 6a-c).

Cell proper about $25-50 \mu \mathrm{m}$ long and $20-35 \mu \mathrm{m}$ wide from life when fully extended, $25-56 \mu \mathrm{m}$ long and 18 $28 \mu \mathrm{m}$ wide after protargol staining. Posterior end of cell proper becomes spherical when escaped from lorica (Fig. 6d). Two ellipsoidal (occasionally elongated) macronuclear nodules, $6-14 \times 4-10 \mu \mathrm{m}$ in size after protargol staining; anterior nodule $4-9 \mu \mathrm{m}$ posteriorly to the anterior cell end after protargol staining (Figs. 5a-c, 6e, h). Micronuclei, striae, tentaculoids, accessory combs, contractile vacuole, cytopyge, and capsules not observed. Locomotion by rotation about main cell axis.

Ventral kinety $14-35 \mu \mathrm{m}$ long with 17-28 monokinetids, commences anteriorly to first kinety of right ciliary field, about $2 \mu \mathrm{m}$ posteriorly to the anterior cell end, goes around right ciliary field from the left side and extending parallel to kineties of ciliary field posteriorly (Figs. 5b, d, 6e). Right ciliary field consists of 7-8 kineties, $1-3 \mu \mathrm{m}$ apart; all kineties commenceabout $2 \mu \mathrm{m}$ below the anterior cell end, except for the first kinety that commences about $1 \mu \mathrm{m}$ posteriorly to remaining kineties; the second kinety always shorter with only two or three kinetids; others composed of 6-7 widely spaced monokinetids and one anterior dikinetid, except first kinety comprised of two to four monokinetids and two or three anterior dikinetids; first kinety usually commences below anterior portion of ventral kinety (Figs. 5b, d, 6e, i). Left ciliary field consists of 6-8 kineties about $2 \mu \mathrm{m}$ away from the anterior cell end, and is composed 
of one anterior dikinetid and 1-7 monokinetids, with decreasing length from right to left (Figs. 5c, d, 6f, g). The anterior basal bodies of dikinetids in left and right ciliary field bear elongated cilia, about $5 \mu \mathrm{m}$ long in both live and protargol-stained specimens while the cilia on posterior basal bodies are similar to ones on monokinetids, about $1 \mu \mathrm{m}$ long after protargol staining (Figs. 5a, $6 \mathrm{e}-\mathrm{j})$. Lateral ciliary field begins about $2 \mu \mathrm{m}$ posteriorly to the anterior end of cell, with 9-16 monokinetidal kineties of similar length, with cilia about $1 \mu \mathrm{m}$ long after protargol staining (Figs. 5b, d, 6e). Dorsal kinety 21$41 \mu \mathrm{m}$ long, and consisting of 17-29 dikinetids, begins about $2 \mu \mathrm{m}$ posteriorly to anterior cell end, about 2 and $3 \mu \mathrm{m}$ away from right and left ciliary fields, respectively; only the posterior basal body bearing a cilium about 3$5 \mu \mathrm{m}$ long after protargol staining (Figs. 5c, d, 6f, g). Posterior kinety begins posterior to the middle kinety of the left ciliary field and 12-21 $\mu \mathrm{m}$ apart from the anterior end of cell; 11-22 $\mu \mathrm{m}$ long, consists of 7-9 dikinetids, with only the posterior basal body bearing a cilium about 3$5 \mu \mathrm{m}$ long after protargol staining (Figs. 5c, d, 6f).

Adoral zone of membranelles consists of 18 or 19 collar membranelles with about $20-25 \mu \mathrm{m}$ long cilia, three or four of which extend into buccal cavity; the longest bases about $10 \mu \mathrm{m}$; polykinetid structures could not be recognized (Figs. 5a-d, 6a, d, h). Single buccal membranelle, with polykinetid about $8 \mu \mathrm{m}$ long (Figs. 5b, d, 6h). Argyrophilic fibers insufficiently impregnated to be observed. Endoral membrane not recognized. One middle divider was observed with the oral primordium located left of ventral kinety and posterior to the lateral ciliary field (Fig. 6j).

\section{Neotypification}

The neotypes of Tintinnopsis hemispiralis and $T$. kiaochowensis are designated because (i) the deposited type materials are unknown; (ii) only lorica features are reported in the original description, while the present redescriptions include also cytological and molecular analyses; and (iii) the type locality of the original populations is Qingdao, East China, with no further details [44]. The type location of the two species is nearby the collection site of the present populations (Meng Bay, Ningde, East China; detailed information provided in 'Materials and Methods'), thus meeting the requirement of Article 75.3.6 of the International Code of Zoological Nomenclature [51]. Protargol slides containing the neotype specimens were deposited (see 'Deposition of neotype and other vouched materials'), thus meeting the requirements of Article 75.3.7 of the Code [51]. A neotype is not established for $T$. uruguayensis because the type location corresponds to a different ocean basin [52].

\section{Sequence comparison and phylogenetic analyses}

For the three species investigated, the length, $\mathrm{G}+\mathrm{C}$ content and GenBank accession numbers of the SSU rDNA, ITS1-5.8S rDNA-ITS2 and LSU rDNA sequences are compiled in Table 2. For each of the three loci and concatenated sequences, the topologies of the Maximum Likelihood (ML) and Bayesian Inference (BI) trees were similar and therefore only the ML trees are shown (Figs. 7, 8, 9, S1). Tintinnopsis hemispiralis forms a fullysupported clade with T. subacuta (EU399541 [53];) based on SSU rDNA; both sequences are 99.3\% similar. Based on ITS1-5.8S-ITS2, a sequence previously obtained for this species in Qingdao, China (KU715813 [48];) groups with our sequence, and both are $96.2 \%$ similar. Tintinnopsis kiaochowensis forms a fullysupported clade with T. everta (MG461220 [33];) based on SSU rDNA, and both sequences are $99.0 \%$ similar. The newly sequenced population of $T$. uruguayensis forms a fully-supported clade with the North-Atlantic population of the same species, based on both SSU rDNA and LSU rDNA (JN831838 and JN831923 [25];); the two populations are $100 \%$ identical in both markers. The concatenated tree (Figure S1, Table S1) shows similar relationships than SSU rDNA, except that Tintinnina were inferred as non-monophyletic. This inference is probably artifactual given the well-known monophyly of this suborder [22, 39].

\section{Discussion}

\section{Tintinnopsis hemispiralis}

\section{Comparison with other populations}

The specimens studied here match Tintinnopsis hemispiralis in lorica size and shape [44]. The lorica dimensions reported in the original description (length $=88$ $164 \mu \mathrm{m}$, opening diameter $=34-53 \mu \mathrm{m}$ [44];) overlap with those of our specimens (length $=143-182 \mu \mathrm{m}$, opening diameter $=45-59 \mu \mathrm{m}$; Table 1 ). The originally described population and our specimens also match in a lorica composed of a cylindrical, spiraled collar and an obconical bowl (Figs. 1a, 2b-d). One ITS1-5.8S rDNAITS2 sequence labeled as T. hemispiralis in GenBank [48] presents a relatively high divergence $(3.8 \%)$ compared to our sequence; conspecificity of both populations cannot be confirmed.

\section{Comparison with similar species}

Four congeners, namely Tintinnopsis cochleata (Brandt, 1906) Laackmann, 1913, Tintinnopsis directa Hada, 1932. Tintinnpsis gracilis Kofoid and Campbell, 1929, and Tintinnopsis tubulosoides Meunier, 1910, are similar to our specimens in an elongated lorica with a spiraled collar. Tintinnopsis cochleata differs from our specimens in a sub-hemispherical posterior end and 13 (vs. 3-5) spiral striations in the collar of the lorica [16]. 
Table 2 DNA sequences obtained in this study

\begin{tabular}{|c|c|c|c|c|}
\hline Species & Marker & $\begin{array}{l}\text { Length } \\
\text { (bp) }\end{array}$ & $\begin{array}{l}\text { GC content } \\
(\%)\end{array}$ & GenBank accession number \\
\hline \multirow[t]{3}{*}{ T. hemispiralis } & SSU rDNA & 1644 & 47.45 & MT435073 \\
\hline & ITS1-5.8S rDNA-ITS2 & 493 & 46.04 & MT435060 \\
\hline & LSU rDNA & 1704 & 51.23 & MT435076 \\
\hline \multirow[t]{3}{*}{ T. kiaochowensis } & SSU rDNA & 1681 & 47.06 & MT435074 \\
\hline & ITS1-5.8S rDNA-ITS2 & 418 & 45.93 & MT435061 \\
\hline & LSU rDNA & 1695 & 50.91 & MT435077 \\
\hline \multirow[t]{3}{*}{ T. uruguayensis } & SSU rDNA & 2105 & 47.32 & MT435075 \\
\hline & ITS1-5.8S rDNA-ITS2 & 445 & 44.97 & MT435062 \\
\hline & LSU rDNA & 1687 & 50.50 & MT435078 \\
\hline
\end{tabular}

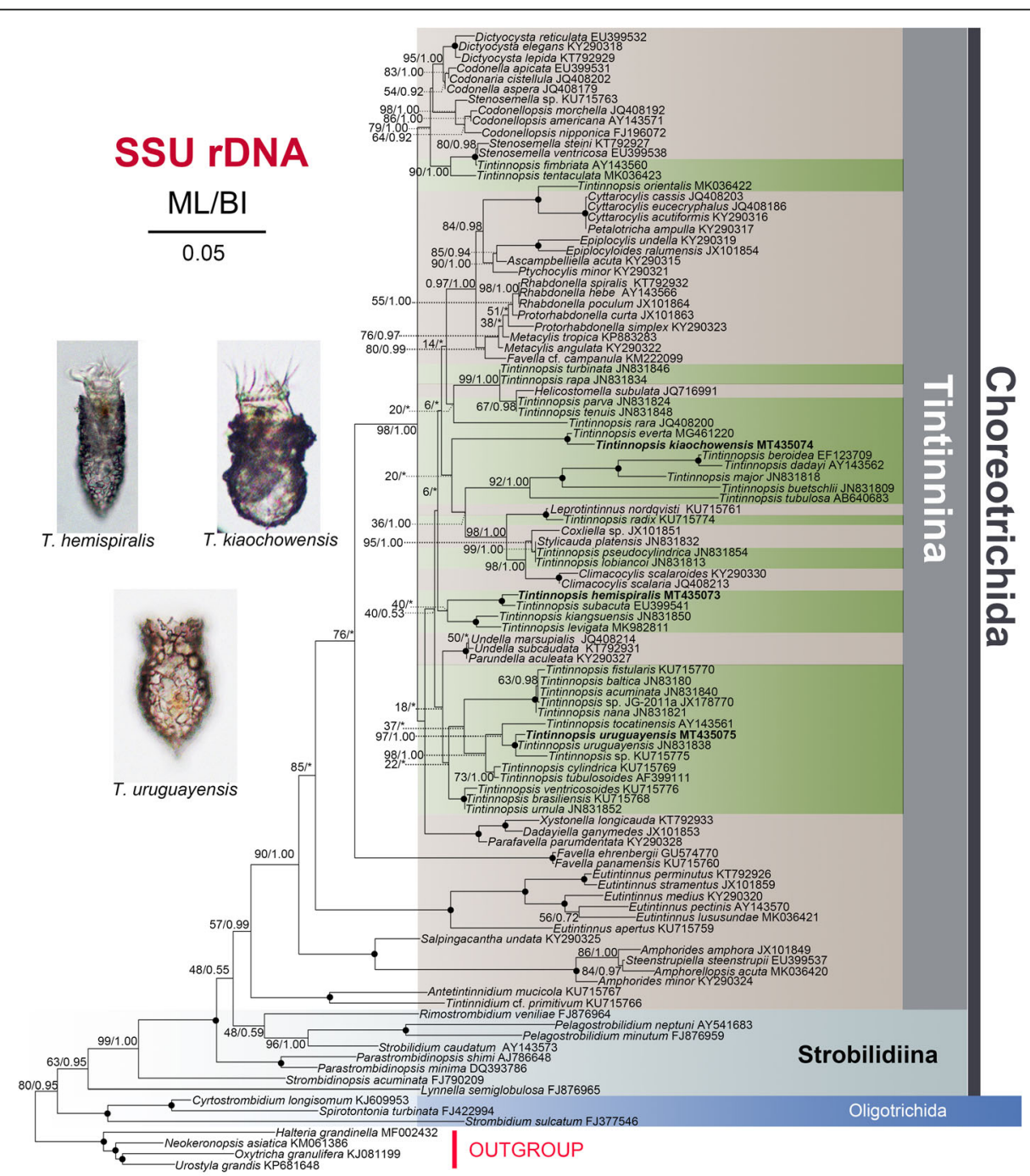

Fig. 7 Maximum likelihood (ML) tree inferred from SSU rDNA sequences, showing nodal support for ML and Bayesian Inference (BI) analyses. Newly sequenced species are shown in bold. Asterisks $\left(^{*}\right)$ reflect disagreements in topology between the BI and $\mathrm{ML}$ trees; black circles reflect fully-supported nodes. The scale bar corresponds to 0.05 substitutions per site 


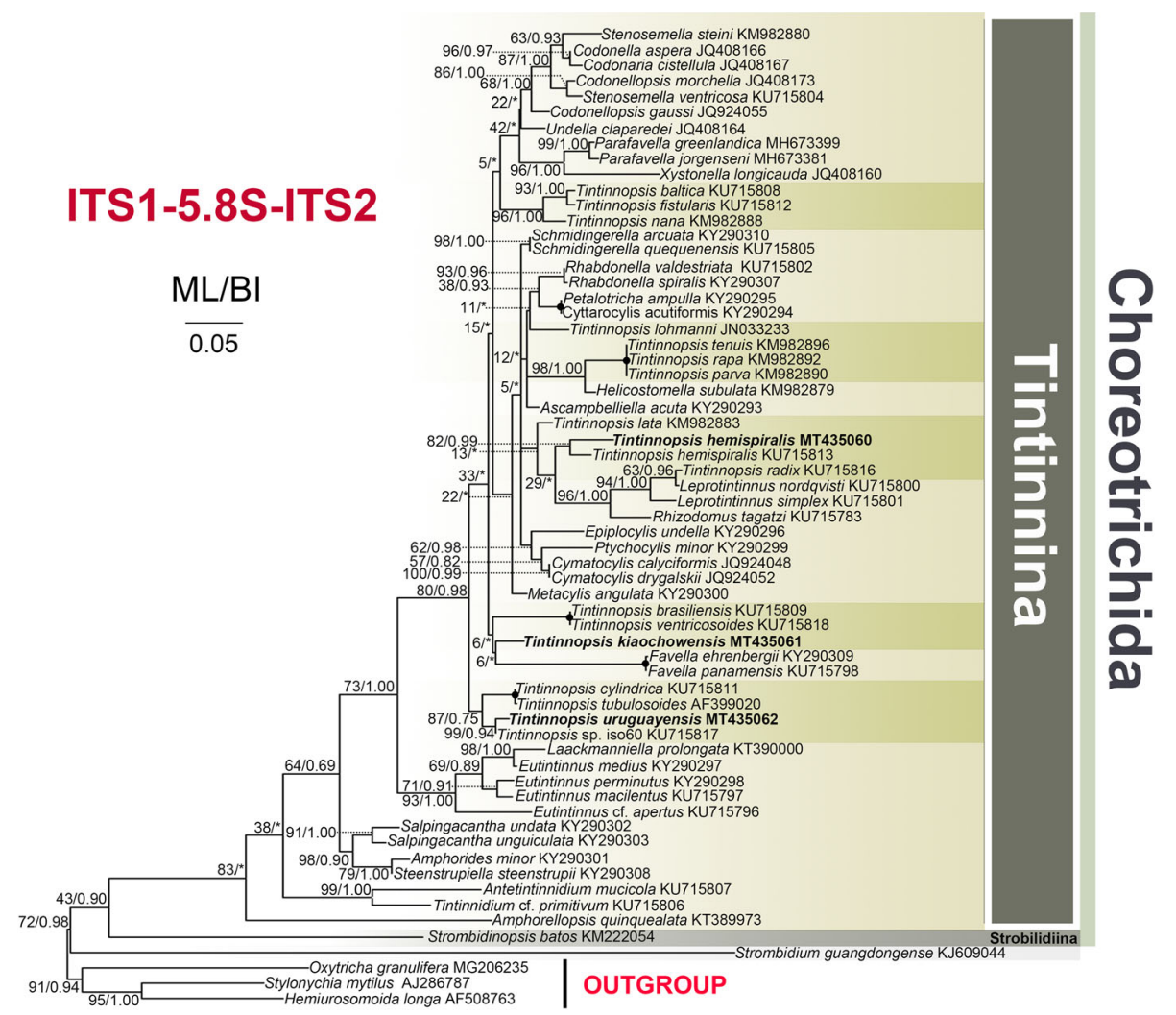

Fig. 8 Maximum likelihood (ML) tree inferred from ITS1-5.8S rDNA-ITS2 sequences, showing nodal support for ML and Bayesian Inference (BI) analyses. Newly sequenced species are shown in bold. Asterisks $\left(^{*}\right)$ reflect disagreements in topology between the Bl and ML trees; black circles reflect fully-supported nodes. The scale bar corresponds to 0.05 substitutions per site

Tintinnopsis directa can be separated from our population by a swollen, ovoid bowl and rounded posterior end of the lorica (vs. coniform, pointed [54];). Tintinnpsis gracilis differs from our specimens by smaller lorica size (110-135 $\mu \mathrm{m}$ long vs. $143-182$ long) and spiraled striation absent in collar portion (vs. 3-5 obvious spiraled striations, see Fig. 2b) [19]. Tintinnopsis tubulosoides differs from our specimens in a smaller lorica size $(91 \mu \mathrm{m}$ long and $33 \mu \mathrm{m}$ in opening diameter, based on the illustration included in the original description) and two (vs. 7-11) macronuclear nodules [55]. For these species, rDNA sequences have been reported only for T. tubulosoides (AF399111-AF399020 [56];), which shows a distant relationship to T. hemispralis (Figs. 7, 8).

Regarding cell features, T. hemispiralis resembles Tintinnopsis subacuta Jörgensen, 1899 in having a ventral kinety associated with the extraordinarily long ciliary tuft that extends outside of the lorica [50]. Both species are also similar in having multiple moniliform macronuclear nodules [50], which differ from the common finding of only two macronuclear nodules in other Tintinnopsis species (e.g., [22, 27, 34]). The two species cluster together based on SSU rDNA (Fig. 7), which suggests that the ciliary tuft and multiple moniliform macronuclear nodules are synapomorphies of this clade and may be important for a future reclassification of Tintinnopsis species. Despite the close relationship between T. hemispiralis and T. subacuta, the latter can be distinguished from our specimens by a lorica with a swollen, ovoid (vs. obconical) bowl in the original description [57] and the micrograph of the sequenced specimen [53]. The SSU rDNA divergence for both species, although small $(0.7 \%)$, is consistent with interspecific variation in this conserved marker [25].

\section{Tintinnopsis kiaochowensis \\ Comparison with type population}

The specimens studied here match Tintinnopsis kiaochowensis in lorica size and shape [44]. The lorica dimensions reported in the original description (length $=95$ $108 \mu \mathrm{m}$, opening diameter $=30-52 \mu \mathrm{m}$ [44];) overlap with those of our specimens (length $=79-112 \mu \mathrm{m}$, opening diameter $=44-71 \mu \mathrm{m}$; Table 1$)$. Our specimens also resemble to those originally described in a lorica with a cylindrical collar and an ellipsoidal bowl with a constricted connection. However, our specimens differ from the original population in the rounded posterior end of the lorica (vs. obconical) and in the agglutinated 


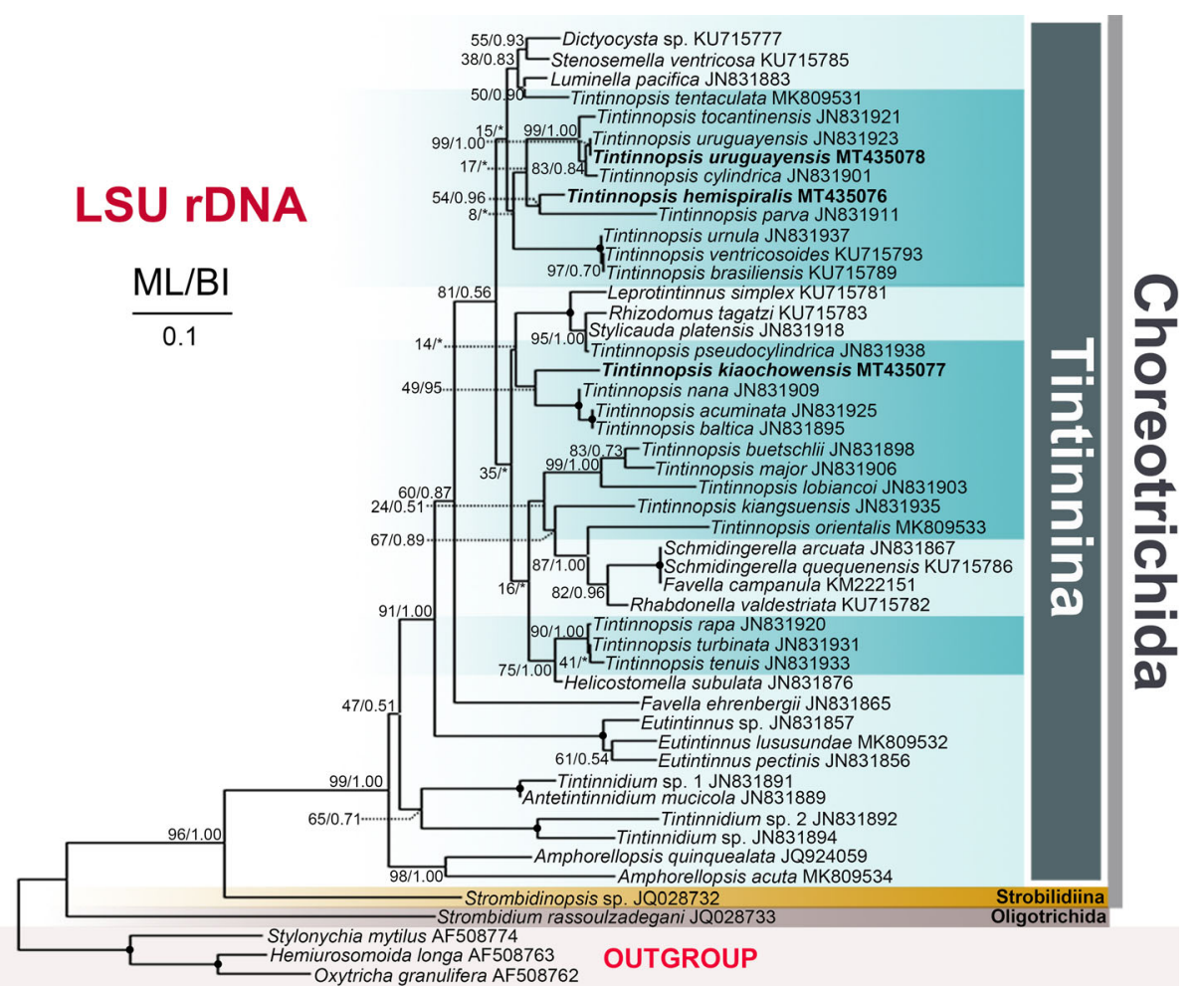

Fig. 9 Maximum likelihood (ML) tree inferred from LSU rDNA sequences, showing nodal support for ML and Bayesian Inference (BI) analyses. Newly sequenced species are shown in bold. Asterisks (*) reflect disagreements in topology between the Bl and ML trees; black circles reflect fully-supported nodes. The scale bar corresponds to 0.1 substitutions per site

particles forming horizontal rows on the collar (vs. both on collar and bowl) [44].

\section{Comparison with similar species}

Tintinnopsis kiaochowensis differs from other Tintinnopsis species by its peculiar lorica shape, i.e. swollen bowl divided from a non-flaring collar by a constriction. Compared to our specimens, the most similar species is Tintinnopsis compressa Daday, 1887. However, T. compressa can be separated from our specimens by having a smaller lorica size ( 45 vs. $79-112 \mu \mathrm{m}$ in length; 26 vs. $44-71 \mu \mathrm{m}$ in opening diameter), a flared lorica collar (vs. not flared), and a less obvious constriction between the lorica collar and bowl [18].

Tintinnopsis kiaochowensis is similar to Tintinnopsis everta Kofoid and Campbell, 1929 based on SSU rDNA (Fig. 7) and cytological characters [33], including: (i) elongated anterior portion of the ventral kinety, which forms a curvature above the third, occasionally the fourth, kinety of the right ciliary filed; (ii) elongated anterior portion of the rightmost kinety of lateral ciliary field, which forms a curvature above the second or third kinety of the right ciliary field (with the ventral kinety in between); and (iii) first four to six kineties of the right ciliary field very widely spaced. However, unique cytological features observed in $T$. everta (the large distance between the collar membranelles and the somatic ciliary fields as well as the position of the posterior kinety [33];) are not present in T. kiaochowensis. Both species also show a different lorica morphology (campanulate lorica with a funnel-shaped collar vs. ellipsoidal bowl and non-flaring collar, respectively) and interspecies-level divergence in SSU rDNA (1\% [25];).

\section{Tintinnopsis uruguayensis Comparison with other populations}

This species was first described by Balech [52] based on the lorica features of specimens collected in the Southwest Atlantic Ocean. The lorica dimensions reported in the original description (length $=54-63 \mu \mathrm{m}$, opening diameter $=22-27 \mu \mathrm{m}$ [52];) overlap with those of our specimens (length $=50-73 \mu \mathrm{m}$, opening diameter $=24$ $42 \mu \mathrm{m}$; Table 1), and both populations match in the characteristic bullet-like shape with a flared collar and a posterior process. Our population presents no divergence in SSU rDNA and LSU rDNA when compared against Long Island Sound specimens of similar lorica features [25]. 


\section{Comparison with similar species}

In terms of a small, bullet-like lorica, three congeners, namely Tintinnopsis baltica Brandt, 1896, Tintinnopsis fimbriata Meunier, 1919, and Tintinnopsis meunieri Kofoid and Campbell, 1929, can be compared to our population. Tintinnopsis baltica has a similar lorica shape, but can be separated from $T$. uruguayensis by the absence (vs. presence) of a protruding posterior end [58]. Laval-Peuto \& Brownlee [59] provided a diagram of the ciliary pattern of $T$. baltica, which is similar to our specimens in the number of kineties in the right, left, and lateral ciliary fields and the presence of only 2-3 kinetids in the second kinety of right ciliary field, but differs in a shorter ventral kinety. The distant phylogenetic relationship between $T$. uruguayensis and T. baltica based on SSU rDNA and LSU rDNA (Figs. 7, 9) also separates both species. Tintinnopsis fimbriata differs from $T$. uruguayensis by a shorter collar $(10 \mu \mathrm{m}$ vs. up to $20 \mu \mathrm{m})$ and a wider bowl (40-50 $\mu \mathrm{m}$ vs. $25-41 \mu \mathrm{m})$ [60]. Based on cytological data [27], T. fimbriata also differs from the latter in having less kineties in the left ciliary field (4-6 vs. up to 9) and lateral ciliary field (11-14 vs. up to 17). The SSU rDNA sequence labeled as $T$. fimbriata in GenBank (Fig. 7) has been considered a misidentification [39] and is thus not considered in this comparison. Tintinnopsis meunieri differs from T. uruguayensis in a larger opening diameter $(60 \mu \mathrm{m}$ vs. $24-$ $42 \mu \mathrm{m})$ [19].

\section{Conclusion}

Tintinnopsis hemispiralis, T. kiaochowensis and T. uruguayensis show hard, fully agglomerated loricae and the most complex pattern of somatic ciliature known for the genus, i.e. a right, left and lateral ciliary field as well as a ventral, dorsal and posterior kinety [22]. However, the three species show differences in the lorica outline and the number, structure and arrangement of somatic kineties (Figs. 1, 2, 3, 4, 5 and 6; Table 1), and species-level divergence in rRNA genes [25, 26]. Their distant position and intertwining with other genera in phylogenetic trees (Figs. 7, 8, 9) confirm, once again, the nonmonophyly of the genus Tintinnopsis [22, 38, 39].

Tintinnopsis cannot be revised at present, as its type species and most other tintinnine species have not been studied cytologically or genetically [23]. Our work is important to increase the number of tintinnine species investigated with modern methods, which also helps in identifying potential synapomorphies for future taxonomic rearrangements. Our data show the potential taxonomic relevance of (i) details of the somatic ciliary pattern, including the anterior parts of the ventral kinety and the rightmost kinety of the lateral ciliary field [33]; and (ii) the presence of a ciliary tuft and multiple moniliform macronuclear nodules. Our paper contributes important information on the non-monophyletic Tintinnopsis and it thus helps to fill the gaps in modern tintinnine taxonomy.

\section{Methods}

\section{Sample collection and morphological analysis}

Tintinnopsis hemispiralis and Tintinnopis kiaochowensis were collected from surface coastal waters in Meng Bay, Ningde, Fujian Province, China (25 $54^{\prime} 24^{\prime \prime} \mathrm{N} 119^{\circ} 40^{\prime} 22^{\prime \prime}$ $\mathrm{E}$; temperature $=25^{\circ} \mathrm{C}$; salinity $=30$ ) on May 28, 2018

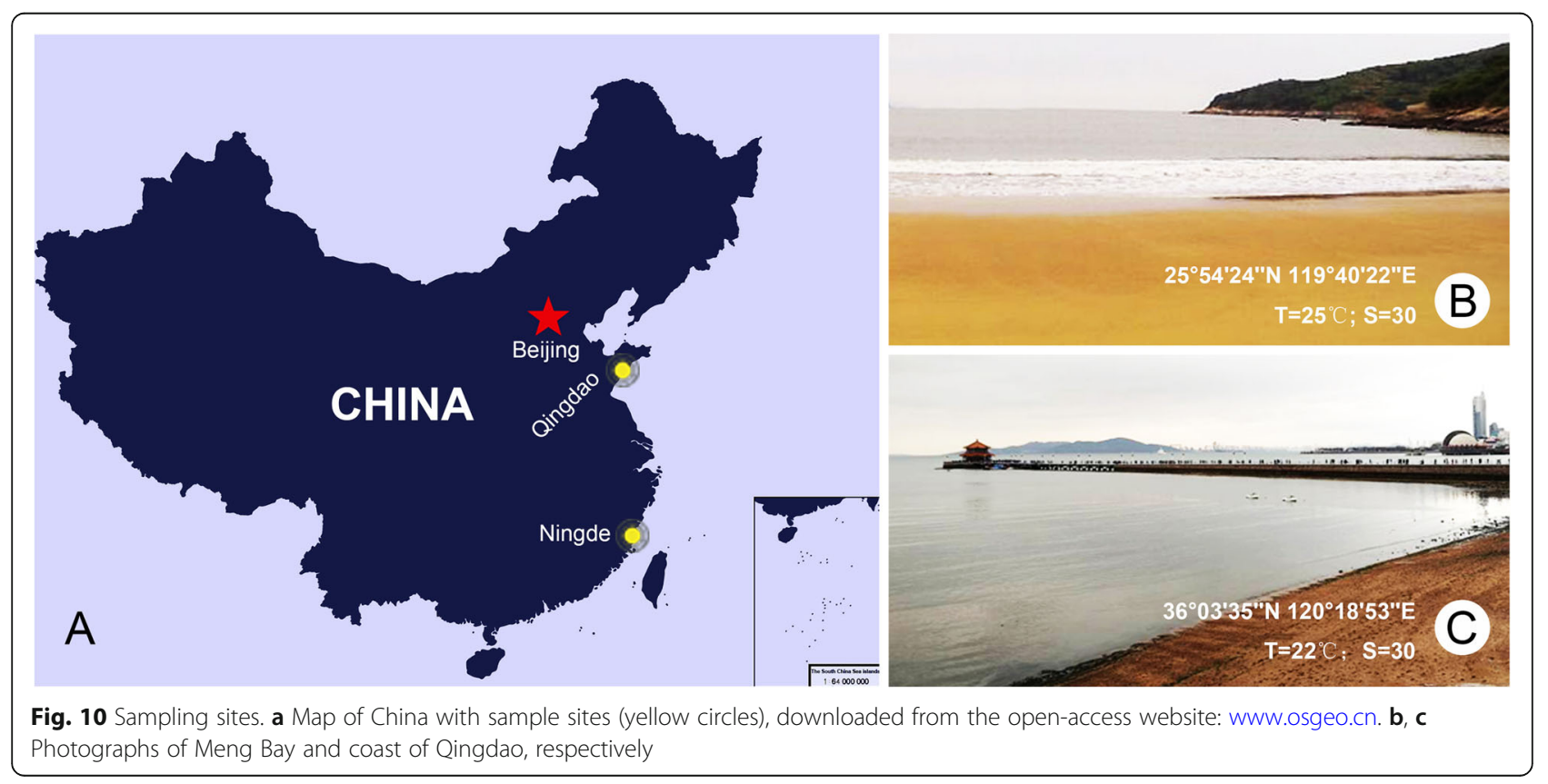


(Fig. 10a, b); Tintinnopsis uruguayensis was collected from surface coastal waters off Qingdao, Shandong Province, China $\left(36^{\circ} 03^{\prime} 35^{\prime \prime} \mathrm{N} 120^{\circ} 18^{\prime} 53^{\prime \prime} \mathrm{E}\right.$; temperature = $22^{\circ} \mathrm{C}$; salinity $=30$ ) on November 12, 2018 (Fig. 10a, c).

Live cells were observation and protargol staining were performed as Bai et al. [31]. Loricae were measured from living cells at magnifications 100-400x with accuracy $1 \mu \mathrm{m}$. Identifications were based on original descriptions $[44,52]$ and other tintinnine bibliography mentioned above. Terminology and classification follow Agatha \& Riedel-Lorjé [61] and Adl et al. [62], respectively.

\section{DNA extraction, PCR amplification and sequencing}

Because most tintinnine species are not amenable to culture, clonal cultures could not be established. Thus, we applied common criteria to verify that field-isolated specimens were not confounded with other species (e.g. as done by Gruber et al. [33]): the three species were distinguished by careful evaluation of their morphological features and lorica size in vivo, and the absence of potentially confounding, co-occurring species was confirmed with further analyses of loricae and protargolstained cells. For each species, a single specimen was isolated at 400× magnification and washed five times with $0.22-\mu \mathrm{m}$ filtered sample water. DNA extraction, PCR amplification and sequencing were done as detailed by Bai et al. [31], except for some of the primers utilized. PCR amplification of the SSU rDNA was performed with the primers 82F (5'-GAA ACT GCG AAT GGC TC-3' [63];) and either 5.8 s-R (5' -CTG ATA TGC TTA AGT TCA GCG G-3' [64];) for Tintinnopsis uruguayensis or $18 \mathrm{~s}-\mathrm{R}$ (5'-TGA TCC TTC TGC AGG TTC ACC TAC3' [65];) for the other two species. A fragment containing the ITS1, 5.8S rDNA and ITS2 regions was amplified with the primers $5.8 \mathrm{~s}-\mathrm{F}$ ( $5^{\prime}$-GTA GGT GAA CCT GCG GAA GGA TC-3') and $5.8 \mathrm{~s}-\mathrm{R}$ (5'-CTG ATA TGC TTA AGT TCA GCG G-3') [64].

Sequences were assembled and analysed as reported before [31]. In brief, phylogenetic analyses were done separately for SSU rDNA, ITS1-5.8S rDNA-ITS2 and LSU rDNA, as well as after concatenating the three sequence markers. The analyse incorporated additional ciliate sequences were obtained from GenBank and used Halteria grandinella and hypotrichs as outgroup taxa. Sequences were aligned with Muscle 3.7 [66]. Maximum likelihood analyses were done with RAxML v. 8 [67], using the GTRG AMMA model and 1000 bootstraps. Bayesian Inference analyses were done with MrBayes v.3.2.6 [68], using the GTR $+\mathrm{I}+\Gamma$ model, 6000,000 generations with a sample frequency of 100 generations and a burn-in of 6000 trees. Estimates of sequence similarity were done in MEGA 7.0 [69].

\section{Supplementary Information}

The online version contains supplementary material available at https://doi. org/10.1186/s12866-020-02057-2.

\begin{abstract}
Additional file 1: Figure S1. Maximum likelihood (ML) tree inferred from concatenated rDNA loci (SSU rDNA, ITS1-5.8S-ITS2 and LSU rDNA) showing nodal support for ML and Bl analyses. Newly sequenced species, i.e., Tintinnopsis hemispiralis, T. kiaochowensis, and T. uruguayensis are shown in bold. See Table S1 for GenBank accession numbers. All species possess SSU rDNA; species including ITS1-5.8S-ITS2 were marked with red stars; species including LSU rDNA were marked with green circles. Species with no marks include the three loci. Asterisks $\left(^{*}\right)$ reflect disagreements in topology between the Bl and ML trees; black circles reflect fully-supported nodes. The scale bar corresponds to 0.1 expected substitutions per site. Table S1. List of sequences of concatenated tree. Newly sequenced species, i.e., Tintinnopsis hemispiralis, T. kiaochowensis, and T. uruguayensis are shown in bold.
\end{abstract}

\section{Abbreviations}

BM: Buccal membranelle; CM: Collar membranelle; CV: Coefficient of variation in \%; DK: Dorsal kinety; EM: Endoral membrane; LA: Lateral ciliary field; LF: Left ciliary field; M: Median; Ma: Macronuclear nodules; Max: Maximum; Mean: Arithmetic mean; Min: Minimum; N: Number of specimens examined; PCM: Prolonged collar membranelles; PK: Posterior kinety; RF: Right ciliary field; SD: Standard deviation; VK: Ventral kinety

\section{Acknowledgements}

We thank Prof. Weibo Song, Ocean University of China for his long-term support and concern on first author. We are also grateful to the editor and anonymous reviewers for their constructive suggestions.

\section{Authors' contributions}

$\mathrm{XH}$ conceived and guided the study. $\mathrm{YB}, \mathrm{RW}$, and WS conducted sampling and performed laboratory work. XH, WS, LL, and YB identified the species. YB and LS did and interpreted the sequence similarity and phylogenetic analyses. YB drafted the manuscript, and WS, LL, LS and XH made further revisions. All authors read and approved this manuscript.

\section{Funding}

This work was supported by the National Natural Science Foundation of China (project numbers: 41776133, 31801955, 31772431). The funding bodies had no role in study design, data collection and analysis, decision to publish, or preparation of the manuscript.

\section{Availability of data and materials}

Sequence data is available in GenBank (Accession Numbers: MT435060MT435062, MT435073-MT435078). Permanent slides containing the protargol-stained specimens of Tintinnopsis hemispiralis, T. kiaochowensis, and T. uruguayensis with registration numbers of BY201805280101, BY201805280102, BY201805280201, BY201805280202, BY201811120101, and BY201811120102 are Laboratory of Protozoology, Institute of Evolution and Marine Biodiversity, Ocean University of China.

\section{Ethics approval and consent to participate}

No field permissions were necessary to collect the samples for this study. The authors declared that the experimental research on the protists described in this paper was in compliance with institutional, national and international guidelines.

\section{Consent for publication}

Not applicable.

\section{Competing interests}

The authors declare that they have no competing interests.

\section{Author details}

${ }^{1}$ College of Fisheries, \& Key Laboratory of Mariculture, Ministry of Education, Ocean University of China, Qingdao 266003, China. ${ }^{2}$ Institute of Evolution and Marine Biodiversity, Ocean University of China, Qingdao 266003, China. ${ }^{3}$ Marine College, Shandong University, Weihai 264209, China. ${ }^{4}$ Department of 
Ecology and Evolutionary Biology and Department of Marine Sciences, University of Connecticut, One University Place, Stamford, CT 06901, USA.

\section{Received: 12 May 2020 Accepted: 2 December 2020 Published online: 14 December 2020}

\section{References}

1. Agatha S. Updated hypothesis on the evolution of oligotrichid ciliates (Ciliophora, Spirotricha, Oligotrichida) based on somatic ciliary patterns and ontogenetic data. Eur J Protistol. 2011:47:51-6.

2. Dolan JR. Morphology and ecology in tintinnid ciliates of the marine plankton: correlates of lorica dimensions. Acta Protozool. 2010;49:235-44.

3. Gao F, Warren A, Zhang O, Gong J, Miao M, Sun P, et al. The all-data-based evolutionary hypothesis of ciliated protists with a revised classification of the phylum Ciliophora (Eukaryota, Alveolata). Sci Rep. 2016;6:24874.

4. Song WB, Warren A, Hu XZ. Free-living ciliates in the Bohai and yellow seas, China. Beijing: Science Press; 2009.

5. Xu DP, Jiao NZ, Ren R, Warren A. Distribution and diversity of microbial eukaryotes in bathypelagic waters of the South China Sea. J Eukaryot Microbiol. 2017:64:370-82.

6. Dolan JR, Pierce RW. Diversity and distributions of tintinnids. In: Dolan JR, Montagnes DJS, Agatha S, Coats WD, Stoecker DK, editors. The biology and ecology of tintinnid ciliates: models for marine plankton. Oxford: WileyBlackwell; 2013. p. 214-43.

7. Santoferrara LF, Rubin E, Mcmanus GB. Global and local DNA (meta) barcoding reveal new biogeography patterns in tintinnid ciliates. J Plankton Res. 2018;40:209-21.

8. Garcia MD, de Cao MSB. Anthropogenic pollution along the coast of a temperate estuary: effects on tintinnid assemblages. Hydrobiologia. 2018; 809:201-19.

9. Jiang $Y, X u H, H u X Z$, Warren A, Song W. Functional groups of marine ciliated protozoa and their relationships to water quality. Environ Sci Pollut R. 2013;20:5272-80.

10. Rakshit D, Sahu G, Mohanty AK, Satpathy KK, Jonathan MP, Murugan K, et al. Bioindicator role of tintinnid (Protozoa: Ciliophora) for water quality monitoring in Kalpakkam, Tamil Nadu, south east coast of India. Mar Pollut Bull. 2017:114:134-43.

11. Sivasankar R, Ezhilarasan P, Kumar PS, Naidu SA, Rao GD, Kanuri W, et al. Loricate ciliates as an indicator of eutrophication status in the estuarine and coastal waters. Mar Pollut Bull. 2018;129:207-11.

12. Jonsson PR, Johansson M, Pierce RW. Attachment to suspended particles may improve foraging and reduce predation risk for tintinnid ciliates. Limnol Oceanogr. 2004;49:1907-14.

13. Zingel $P$, Agasild $H$, Karus $K$, Buholce L, Nõges T. Importance of ciliates as food for fish larvae in a shallow sea bay and a large shallow lake. Eur J Protistol. 2019;67:59-70.

14. Dunthorn M, Lipps J, Dolan JR, Abboud-Abi Saab M, Aescht E, Bachy C, et al. Ciliates - Protists with complex morphologies and ambiguous early fossil record. Mar Micropaleontol. 2015;119:1-6.

15. Lipps JH, Stoeck T, Dunthorn M. Fossil tintinnids. In: Dolan JR, Montagnes DJS, Agatha S, Coats WD, Stoecker DK, editors. The biology and ecology of tintinnid ciliates: models for marine plankton. Oxford: Wiley-Blackwell; 2013. p. 186-97.

16. Brandt K. Die Tintinnodeen der Plankton Expedition. Tafelerklarungen nebst kurzer Diagnose der neuen Arten. In: Hensen V, editor. Ergebnisse der Plankton-Expedition der Humboldt-Stiftung 3 La. Kiel, Leipzig: Lipsius and Tischer; 1906. p. 1-33.

17. Brandt K. Die Tintinnodeen der plankton expedition Systematischer Teil. In: Hensen V, editor. Ergebnisse der plankton-expedition der HumboldtStiftung 3 La. Kiel, Leipzig: Lipsius and Tischer; 1907. p. 1-488.

18. Daday E. Monographie der Familie der Tintinnodeen. Mitt Zool Stn Neapel. 1887;7:473-591.

19. Kofoid CA, Campbell AS. A conspectus of the marine and fresh-water Ciliata belonging to the suborder Tintinnoinea, with descriptions of new species principally from the Agassiz expedition to the eastern tropical Pacific 19041905. Univ Calif Publ Zool. 1929:34:1-403.

20. Kofoid CA, Campbell AS. Reports on the scientific results of the expedition to the eastern tropical Pacific, in charge of Alexander Agassiz, by the U. S. Fish Commission Steamer "Albatross," from October, 1904, to March, 1905, Lieut. Commander L M Garrett, U S N Commanding XXXVII. The Ciliata: the Tintinnoinea. Bull Mus Comp Zool Harv. 1939;84:1-473.
21. Zhang WC, Feng MP, Yu Y, Zhang CX, Xiao T. An illustrated guide to contemporary tintinnids in the world. Beijing: Science Press; 2012

22. Agatha S, Strüder-Kypke MC. Systematics and evolution of tintinnid ciliates. In: Dolan JR, Montagnes DJS, Agatha S, Coats WD, Stoecker DK, editors. The biology and ecology of tintinnid ciliates: models for marine plankton. Oxford: Wiley-Blackwell; 2013. p. 42-84.

23. Santoferrara LF, Bachy C, Alder VA, Gong J, Kim YO, Saccà A, et al. Updating biodiversity studies in loricate protists: the case of the tintinnids (Alveolata, Ciliophora, Spirotrichea). J Eukaryot Microbiol. 2016;63:651-6.

24. Laval-Peuto M. Construction of the lorica in Ciliata Tintinnina. In vivo study of Favella ehrenbergii: variability of the phenotypes during the cycle, biology, statistics, biometry. Protistologica. 1981;17:249-72.

25. Santoferrara LF, McManus GB, Alder VA. Utility of genetic markers and morphology for species discrimination within the order Tintinnida (Ciliophora, Spirotrichea). Protist. 2013;164:24-36.

26. Santoferrara LF, Tian M, Alder V, McManus G. Discrimination of closely related species in tintinnid ciliates: new insights on crypticity and polymorphism in the genus Helicostomella. Protist. 2015;166:78-92.

27. Agatha S. Redescription of the tintinnid ciliate Tintinnopsis fimbriata Meunier, 1919 (Spirotricha, Choreotrichida) from coastal waters of northern Germany. Denisia. 2008;23:261-72.

28. Agatha S. Redescription of Tintinnopsis parvula Jörgensen, 1912 (Ciliophora: Spirotrichea: Tintinnina), including a novel lorica matrix. Acta Protozool. 2010;49:213-34

29. Agatha S. A light and scanning electron microscopic study of the closing apparatus in tintinnid ciliates (Ciliophora, Spirotricha, Tintinnina): a forgotten synapomorphy. J Eukaryot Microbiol. 2010;57:297-307.

30. Agatha S, Tsai SF. Redescription of the tintinnid Stenosemella pacifica Kofoid and Campbell 1929 (Ciliophora, Spirotricha) based on live observation, protargol impregnation, and scanning electron microscopy. J Eukaryot Microbiol. 2008;55:75-85

31. Bai Y, Wang R, Liu WW, Warren A, Zhao Y, Hu XZ. Redescriptions of three tintinnine ciliates (Ciliophora: Tintinnina) from coastal waters in China based on lorica features, cell morphology, and rDNA sequence data. Eur J Protistol. 2020;72:125659

32. Bai $Y$, Wang $R$, Song $W$, Suzuki $T$, Hu XZ. Redescription of five tintinnine ciliates (Alveolata: Ciliophora: Oligotrichea) from coastal waters of Qingdao. China Mar Life Sci Technol. 2020:2:209-21.

33. Gruber MS, Strüder-Kypke M, Agatha S. Redescription of Tintinnopsis everta Kofoid \& Campbell, 1929 (Alveolata, Ciliophora, Tintinnina) based on taxonomic and genetic analyses-discovery of a new complex ciliary pattern. J Eukaryot Microbiol. 2018;65:484-504.

34. Jiang Y, Yang JP, Al-Farraj S, Warren A, Lin XF. Redescriptions of three tintinnid ciliates, Tintinnopsis tocantinensis, T. radix, and T. cylindrica (Ciliophora, Spirotrichea), from coastal waters off China. Eur J Protistol. 2012; 48:314-25.

35. Smith SA, Song W, Gavrilova NA, Kurilov AV, Liu WW, McManus GB, et al Dartintinnus alderae n. g., n. sp., a brackish water tintinnid (Ciliophora, Spirotrichea) with dual-ended lorica collapsibility. J Eukaryot Microbiol. 2018, 65:400-11.

36. Wang R, Song W, Bai Y, Warren A, Li LF, Hu XZ. Morphological redescriptions and neotypification of two poorly known tintinnine ciliates (Alveolata, Ciliophora, Tintinnina), with a phylogenetic investigation based on SSU rRNA gene sequences. Int J Sys Evol Microbiol. 2020;70:2515-30.

37. Santoferrara L, McManus G. Diversity and biogeography as revealed by morphologies and DNA sequences: Tintinnid ciliates as an example. In: Barbosa A, Teodósio MA, editors. Zooplankton ecology. CRC Press: Taylor \& Francis Group; 2021. p. 85-118. https://doi.org/10.1201/9781351021821-7.

38. Agatha S, Strüder-Kypke MC. Phylogeny of the order Choreotrichida (Ciliophora, Spirotricha, Oligotrichea) as inferred from morphology, ultrastructure, ontogenesis, and SSU rRNA gene sequences. Eur J Protistol. 2007:43:37-63.

39. Santoferrara LF, Alder W, McManus GB. Phylogeny, classification and diversity of Choreotrichia and Oligotrichia (Ciliophora, Spirotrichea). Mol Phylogenet Evol. 2017;112:12-22.

40. Feng MP, Wang C, Zhang WC, Zhang G, Xu H, Zhao Y, et al. Dataset of long term variation in species occurrence and abundance of tintinnid assemblages in Jiaozhou Bay, China. Data Brief. 2018:19:1856-64.

41. Hu XZ, Lin XF, Song WB. Ciliate atlas: species found in the South China Sea. Beijing: Science Press; 2019

42. Liu LR. Checklist of marine biota of China seas. Beijing: Science Press; 2008. 
43. Xu DP, Song WB. Tintinnid ciliates from Qingdao (Protozoa, Ciliophora, Tintinnida). Acta Zootaxon Sin. 2005;30:501-8.

44. Yin GD. Three new species of Tintinnopsis collected from Kiaochow Bay, Shantung, China. China J Shandong Univ. 1956;2:64-9.

45. Li ZC, Yi ZZ, Yang JP, Gong J, Clamp JC, Al-Rasheid KAS, et al. Phylogenetic investigation on five genera of tintinnid ciliates (Ciliophora, Choreotrichia), based on the small subunit ribosomal RNA gene sequences. Prog Nat Sci. 2009;19:1097-101.

46. Wang YR, Wang CD, Jiang YH, Katz LA, Gao F, Yan Y. Further analyses of variation of ribosome DNA copy number and polymorphism in ciliates provide insights relevant to studies of both molecular ecology and phylogeny. Sci China Life Sci. 2019;62:203-14.

47. Xu DP, Sun P, Warren A, Noh J, Choi D, Shin M, Kim Y. Phylogenetic investigations on ten genera of tintinnid ciliates (Ciliophora: Spirotrichea: Tintinnida), based on small subunit ribosomal RNA gene sequences. J Eukaryot Microbiol. 2013;60:192-202.

48. Zhang QQ, Agatha S, Zhang WC, Dong J, Yu Y, Jiao NZ, Gong J. Three rDNA loci-based phylogenies of tintinnid ciliates (Ciliophora, Spirotrichea, Choreotrichida). J Eukaryot Microbiol. 2017:64:226-41.

49. Warren A, Patterson DJ, Dunthorn M, Clamp JC, Achilles-Day UE, Aescht E, et al. Beyond the "code": a guide to the description and documentation of biodiversity in ciliated protists (Alveolata, Ciliophora). J Eukaryot Microbiol. 2017;64:539-54.

50. Mühlthaler A, Kagerer M, Agatha S. The Rapunzel tintinnid-redescription of Tintinnopsis subacuta Jörgensen, 1899 (Alveolata, Ciliophora, Spirotricha). Protistology. 2016;10:48-9.

51. ICZN. (international commission on zoological nomenclature). International code of zoological nomenclature. London: International Trust for Zoological Nomenclature; 1999

52. Balech E. Tintinnoinea de Atlantida (R. O. del Uruguay). Comun Mus argent Cienc Nat Bernardino Rivadavia. Serie Ciencias Zool. 1948;7:1-23.

53. Strüder-Kypke MC, Lynn DH. Morphological versus molecular dataphylogeny of tintinnid ciliates (Ciliophora, Choreotrichia) inferred from small subunit rRNA gene sequences. Denisia. 2008;23:417-24.

54. Hada Y. Report of the biological survey of Mutsu Bay. 24. The pelagic Ciliata, suborder Tintinnoinea. Sci Rep Tohoku Imp Univ. 1932;7:553-73.

55. Meunier A. Microplankton des mers de Barent et de Kara. Duc d'Orle' ans, Campagne arctique de 1907. Bruxelles: Bulen; 1910.

56. Snoeyenbos-West OL, Salcedo T, McManus GB, Katz LA. Insights into the diversity of choreotrich and oligotrich ciliates (class: Spirotrichea) based on genealogical analyses of multiple loci. Int J Syst Evol Microbiol. 2002;52: 1901-13.

57. Jörgensen E. Ueber die Tintinnodeen der norwegischen Westkuste. Bergen Mus Aaebog. 1899;2:1-48.

58. Brandt K. Die Tintinnen. Biblthca Zool. 1896;8:45-72.

59. Laval-Peuto M, Brownlee DC. Identification and systematics of the Tintinnina (Ciliophora): evaluation and suggestions for improvement. Ann Inst Oceanogr. 1986;62:69-84.

60. Meunier A. Mikroplankton de la mer Flamande. III. Les Péridiniens. Mém Mus Roy Hist Nat Belgique. 1919;8:1-116.

61. Agatha S, Riedel-Lorjé JC. Redescription of Tintinnopsis cylindrica Daday, 1887 (Ciliophora: Spirotricha) and unification of tintinnid terminology. Acta Protozool. 2006;45:137-51.

62. Adl SM, Bass D, Lane CE, Lukes J, Schoch CL, Smirnov A, et al. Revisions to the classification, nomenclature, and diversity of eukaryotes. J Eukaryot Microbiol. 2019;66:4-119.

63. Jerome CA, Lynn DH, Simon EM. Description of Tetrahymena empidokyrea $n$. sp., a new species in the Tetrahymena pyriformis sibling species complex (Ciliophora, Oligohymenophorea), and an assessment of its phylogenetic position using small-subunit rRNA sequences. Can J Zool. 1996;74:1898-906.

64. Lu B, Li L, Hu XZ, Ji D, Al-Rasheid KA, Song WB. Novel contributions to the peritrich family Vaginicolidae (Protista: Ciliophora), with morphological and phylogenetic analyses of poorly known species of Pyxicola, Cothurnia and Vaginicola. Zool J Linnean Soc. 2019;187:1-30.

65. Medlin L, Elwood HJ, Stickel S, Sogin ML. The characterization of enzymatically amplified eukaryotic 16S-like rRNA-coding regions. Gene. 1988;71:491-9.

66. Edgar RC. MUSCLE: multiple sequence alignment with high accuracy and high throughput. Nucleic Acids Res. 2004;32:1792-7.

67. Stamatakis A. 2014. RAxML version 8: a tool for phylogenetic analysis and post-analysis of large phylogenies. Bioinformatics. 2014;30:1312-3.
68. Ronquist F, Teslenko M, Van Der Mark P, Ayres DL, Darling A, Höhna S, et al. MrBayes 3.2: efficient Bayesian phylogenetic inference and model choice across a large model space. Syst Biol. 2012;61:539-42.

69. Kumar S, Stecher G, Tamura K. MEGA7: molecular evolutionary genetics analysis version 7.0 for bigger datasets. Mol Phylogenet Evol. 2016;33: $1870-4$

\section{Publisher's Note}

Springer Nature remains neutral with regard to jurisdictional claims in published maps and institutional affiliations.
Ready to submit your research? Choose BMC and benefit from:

- fast, convenient online submission

- thorough peer review by experienced researchers in your field

- rapid publication on acceptance

- support for research data, including large and complex data types

- gold Open Access which fosters wider collaboration and increased citations

- maximum visibility for your research: over $100 \mathrm{M}$ website views per year

At $\mathrm{BMC}$, research is always in progress.

Learn more biomedcentral.com/submissions 